\title{
A Review of Red Yeast Rice, a Traditional Fermented Food in Japan and East Asia: Its Characteristic Ingredients and Application in the Maintenance and Improvement of Health in Lipid Metabolism and the Circulatory System
}

\author{
Hiroyuki Fukami $^{1, *}$, Yuki Higa ${ }^{1}\left(\mathbb{D}\right.$, Tomohiro Hisano ${ }^{1}$, Koichi Asano ${ }^{1}$, Tetsuya Hirata ${ }^{1}$ and Sansei Nishibe ${ }^{2}$ \\ 1 Central R\&D Laboratory, KOBYASHI Pharmaceutical Co., Ltd., Ibaraki 567-0057, Japan; \\ y.higa@kobayashi.co.jp (Y.H.); t.hisano@kobayashi.co.jp (T.H.); ko.asano@kobayashi.co.jp (K.A.); \\ t.hirata@kobayashi.co.jp (T.H.) \\ 2 Faculty of Pharmaceutical Sciences, Health Sciences University of Hokkaido, Ishikari 061-0293, Japan; \\ nishibe@hoku-iryo-u.ac.jp \\ * Correspondence: h.fukami@kobayashi.co.jp; Tel.: +81-80-3452-9483; Fax: +81-72-640-0137
}

check for updates

Citation: Fukami, H.; Higa, Y.; Hisano, T.; Asano, K.; Hirata, T.; Nishibe, S. A Review of Red Yeast Rice, a Traditional Fermented Food in Japan and East Asia: Its Characteristic Ingredients and Application in the Maintenance and Improvement of Health in Lipid Metabolism and the Circulatory System. Molecules 2021, 26, 1619. https://doi.org/10.3390/ molecules 26061619

Academic Editors: Alessia Fazio and Pierluigi Plastina

Received: 28 December 2020

Accepted: 5 February 2021

Published: 15 March 2021

Publisher's Note: MDPI stays neutral with regard to jurisdictional claims in published maps and institutional affiliations.

Copyright: (c) 2021 by the authors. Licensee MDPI, Basel, Switzerland. This article is an open access article distributed under the terms and conditions of the Creative Commons Attribution (CC BY) license (https:// creativecommons.org/licenses/by/ $4.0 /)$.
Abstract: Red yeast rice has been used to produce alcoholic beverages and various fermented foods in China and Korea since ancient times; it has also been used to produce tofuyo (Okinawanstyle fermented tofu) in Japan since the 18th century. Recently, monacolin K (lovastatin) which has cholesterol-lowering effects, was found in some strains of Monascus fungi. Since statins have been used world-wide as a cholesterol-lowering agent, processed foods containing natural statins are drawing attention as materials for primary prevention of life-style related diseases. In recent years, large-scale commercial production of red yeast rice using traditional solid-state fermentation has become possible, and various useful materials, including a variety of monascus pigments (polyketides) that spread as natural pigments, in addition to statins, are produced in the fermentation process. Red yeast rice has a lot of potential as a medicinal food. In this paper, we describe the history of red yeast rice as food, especially in Japan and East Asia, its production methods, use, and the ingredients with pharmacological activity. We then review evidence of the beneficial effects of red yeast rice in improving lipid metabolism and the circulatory system and its safety as a functional food.

Keywords: red yeast rice; Monascus fungi; solid-state fermentation; monacolin; statin; LDL-cholesterol; polyketide; pigment; lipid metabolism; cardiovascular system

1. Introduction: Overview of Red Yeast Rice, Its History, Production Method, and Use 1.1. The History behind Koji (Yeast Grain) and Red Yeast Rice (Red Koji)

Every country in the world has its own traditional food culture, and quite a few countries have their own brewed foods, made using different fermentation mechanisms. In contrast to western countries, where malt and fruit juice are used for fermentation, in Eastern and Southeastern Asia, fermented foods are produced using rice and beans malted with filamentous fungus such as Aspergilli. Fungi are widely used since the areas have a climate of high temperatures and humidities.

Koji is made by breeding molds that can be used for food fermentation on grains such as rice, wheat, and soybeans. Miso, soy-sauce, vinegar, mirin (sweet sake), pickles, sake (Japanese rice wine), and distilled spirit are all made from various Koji grains which play a central role in "Wasyoku”, a food culture in Japan.

There are various types of koji and koji molds (also called koji fungi): yellow koji (made with $A$. oryzae), used to produce miso, soy-sauce, mirin and sake; black koji (made with $A$. awamori), used to produce awamori (Okinawan distilled spirit); and black koji or white koji (made with A. Kawachii), used to produce syochuu (Japanese distilled spirits). Red yeast rice (red yeast grain, red koji, Beni-Koji), made with Monascus fungi, has been used to produce 
Tofunyu (fermented bean curd) in Taiwan and China since ancient times and has also been used to produce tofuyo (Okinawan style fermented bean curd) in Japan.

Monascus fungi produce red pigments and the koji produced with Monascus fungi exhibit a deep red color (Figure 1). These red pigments have been used industrially since the 1950s in Japan. For example, they have been used in processed fish paste products, such as crab-flavored-fish cakes and processed meat products, such as ham and sausages. Recently, they have been widely used in various foods including bread, confectionaries and beverages, such as amazake (fermented rice drink).

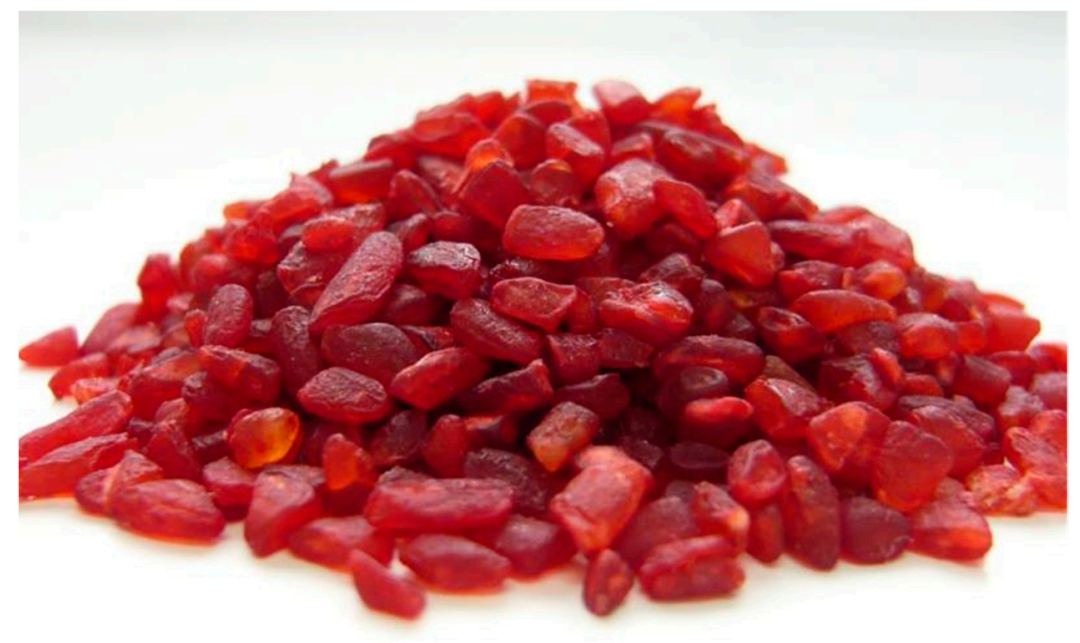

Figure 1. Appearance of red yeast rice.

Red yeast rice is recorded in Bencao Gangmu (Compendium of Materia Medica), a representative book on Chinese medicine, written in 1596 which has been highly valued since ancient times in China. Lovastatin (monacolin $\mathrm{K}$ ), which has cholesterol lowering effects, was found as an active ingredient from Monascus fungi [1-3]. Statins such as lovastatin and its analogs are used world-wide as serum cholesterol lowering agents which are used as first-line drugs for atherosclerotic diseases. Evidence for the beneficial and pleiotropic effects of statins has been reported, and further accumulation of evidence is expected in the future. Red yeast rice also contains lovastatin, and although it is currently used as a functional food, it could be used in the prevention of life-style related diseases to reduce metabolic syndrome and the metabolic domino, through the improvement of dietary habits.

In this study, we review Monascus fungi: their history, production methods of red yeast rice, foods made using red yeast rice, characteristic ingredients, evidence of potential beneficial effects to improve lipid metabolism and the circulatory system, and safety.

\subsection{Monascus Fungi and Red Yeast Rice}

Monascus fungi are taxonomically classified into Hemiascomycetes; they are filamentous fungi belonging to the Ascomycetes class, similar to Aspergillus, which are used in the production of miso, soy-sauce and sake. These Monascus fungi are called red koji mold (or red koji fungi) because they produce red pigments; approximately 20 strains have been identified so far (Table 1). Most of the Monascus fungi were found in red yeast rice and brewed foods or beverages produced with red yeast rice in China, Taiwan, or Korea from the second half of the 1920s to the first half of the 1930s [4]. About 50 strains of Monascus fungi are preserved in the Biological Resource Center, Department of Biotechnology, National Institute of Technology and Evaluation (NITE) in Japan (Table 2) [5]. 
Table 1. Typical Monascus fungi and their isolation source.

\begin{tabular}{cc}
\hline Strain & Source \\
\hline M. purpureus & Red yeast rice, malted rice (miquzi in Chinese) (China, Korea, Taiwan) \\
M. anka & Red yeast rice (Taiwan), malted rice of red nyufu \\
M. anka var. rubellus & Lees from the making process of red Laojiu (Chinese alcoholic beverage) \\
M. barkeri & Malted rice for samutu-syu (Chinese red alcoholic beverage) \\
M. albidus & Chantofu (Shanghai) \\
M. araneosus & Malted rice for gaoliangilu (Chinese distilled spirit, Northeastern China) \\
M. furiginosus & Malted rice (Guizhou Province, China) \\
M. major & Malted rice (Fuzhou, China) \\
M. albidus var. glaber & Malted rice (Fuzhou, China) \\
M. pilosus & Malted rice for gaoliangilu (Fengtian, China) \\
M. rubropanctatus & Malted rice for gaoliangilu (Liaoyang, China) \\
M. pubigerus & Malted rice (Guangdong Province) \\
M. rubinosus & Red funyu (Hong Kong) \\
M. serubescens & Red funyu (Hong Kong) \\
M. vitreus & Powdered malted rice for medicinal wine (Incheon, Korea) \\
M. kaoliang & Malted rice for gaoliangilu (Taiwan) \\
M. ruber & Silage, soil, rotten fruit etc. \\
M. paxi & Dead branch and leaves of plants \\
\hline
\end{tabular}

Table 2. Representative Monascus fungi preserved at the Biological Resource Center (NBRC), NITE in Japan.

\begin{tabular}{|c|}
\hline Strain \\
\hline $\begin{array}{c}\text { M. anka Nakazawa et Sato NBRC } 4478 \\
\text { M. purpreus Went NBRC } 4513 \\
\text { M. anka Nakazawa et Sato (T. Hasegawa) NBRC } 6540 \\
\text { M. major Sato NBRC } 4485 \\
\text { M. ruber van Tieghem NBRC } 4492 \\
\text { M. pubigerus Sato NBRC } 4521 \\
\text { M. araneosus Sato NBRC } 4482 \\
\text { M. rubiginosus Sato NBRC } 4484 \\
\text { M. anka var. rubellus Sato NBRC } 5965 \\
\text { M. ruber van Tieghem (S. Udagawa) NBRC } 9203 \\
\text { M. pilosus Sato (FAT) NBRC } 4520 \\
\text { M. fuliginosus Sato NBRC } 4483 \\
\text { M. pilosus Sato NBRC } 4480 \\
\text { M. paxii Lingelsheim NBRC } 8201 \\
\text { M. vitreus Sato NBRC 4532 } \\
\text { M. vitreus Sato (J. Nicot) NBRC } 7537 \\
\text { M. albidus Sato NBRC 4489 } \\
\text { M. serorubescens Sato NBRC } 4487 \\
\text { M. albidus var. glaber Sato NBRC } 4486 \\
\text { M. serorubescens Sato (FAT) NBRC } 4525\end{array}$ \\
\hline
\end{tabular}

\subsection{Production of Red Yeast Rice}

Red yeast rice is documented as Chinese herbal cuisine that improves blood circulation in Nichiyo-Honzo, a Chinese herbology book written by Duan Wu in 1329. Red yeast rice was also called tan-giku, and its production method is described in Tiangong Kaiwu, a compendium on industry, agriculture and artisanry, written by Song Ying in the 17th century in China (Figure 2) [4,6]. In brief, after soaking in water for 7 days, polished rice is steamed, and the lees of Shaoxing wine are added as seed fungi and cultured in a tile room for about 1 week. Interestingly, the method is very similar to that used in the production of yellow koji in Japan. Monascus fungi (red koji fungi) have low proliferative ability, and about 1 week is required for the production of red yeast rice, though only 2 days are required for 
that of yellow koji. The long-term culture increases the chance of contamination by various germs; therefore, the area of each production process is kept thoroughly clean, and the aseptically cultured red yeast rice is used as the seed fungus.
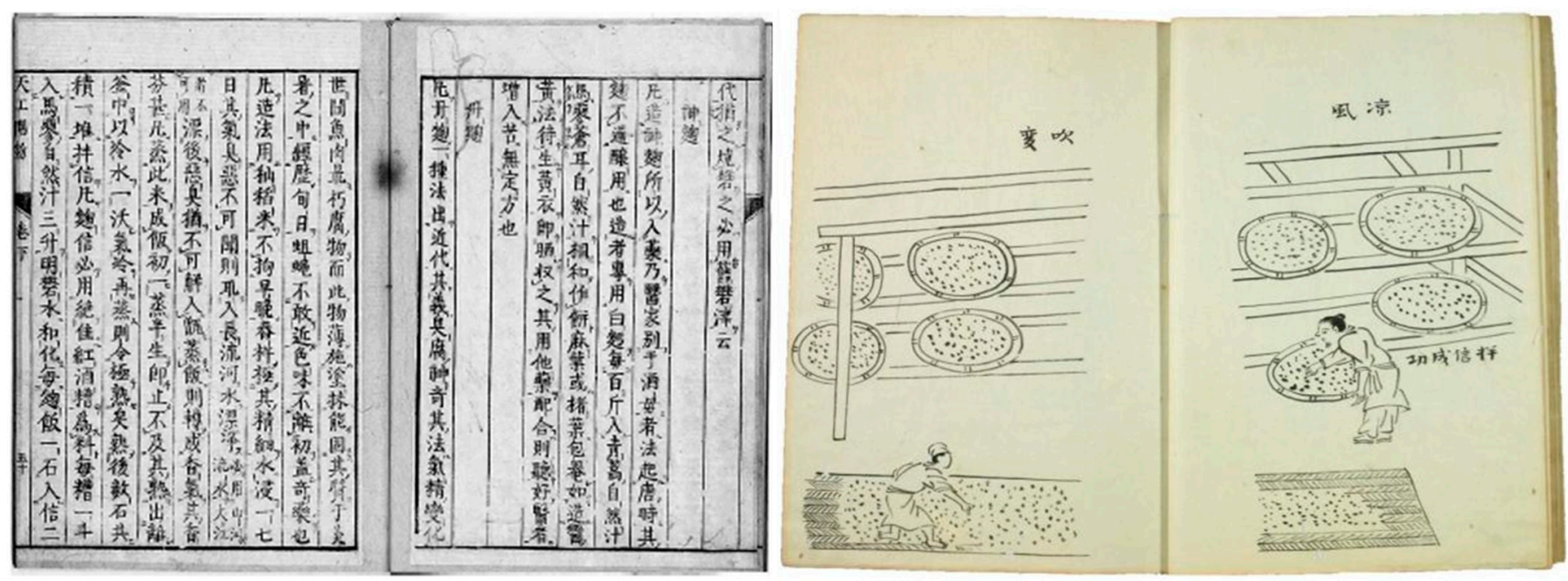

Figure 2. Production method of red yeast rice described in "Tiangong Kaiwu". Rice inoculated with Monascus fungi is divided between several bamboo trays, which are placed on shelves to maintain good air circulation. Ambient air during the culture is a key factor. The room in which the shelves are placed must be wide and there must be a high ceiling. The room must also be facing south to avoid afternoon sunlight and its temperature should be controlled. Rice inoculated with the fungi should be mixed up and down 3 times every $2 \mathrm{~h}$.

Red yeast rice itself has been used in the coloring of foods, meat in particular, in China and Taiwan since ancient times. Red pigments extracted and isolated from red yeast rice have been produced as natural pigments on an industrial scale since 1945. Since the carcinogenicity of synthetic red pigments was discovered, the consumption of natural pigments (red yeast rice pigment) made by Monascus fungi has increased.

The traditional method for the production of red yeast rice-related foods was the solid-state culture method described above; however, the pigments are now industrially produced by simple processes of extraction and concentration from red yeast rice, proliferated by an aerated and agitated culture method (liquid-state culture) (Figure 3) [7].

\section{$\underline{\text { Traditional solid-state fermentation method since ancient }}$}

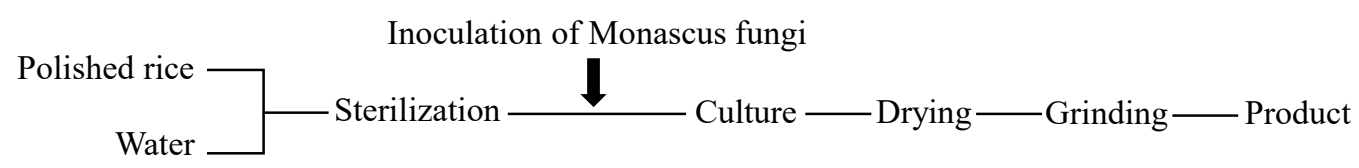

Liquid-state fermentation method

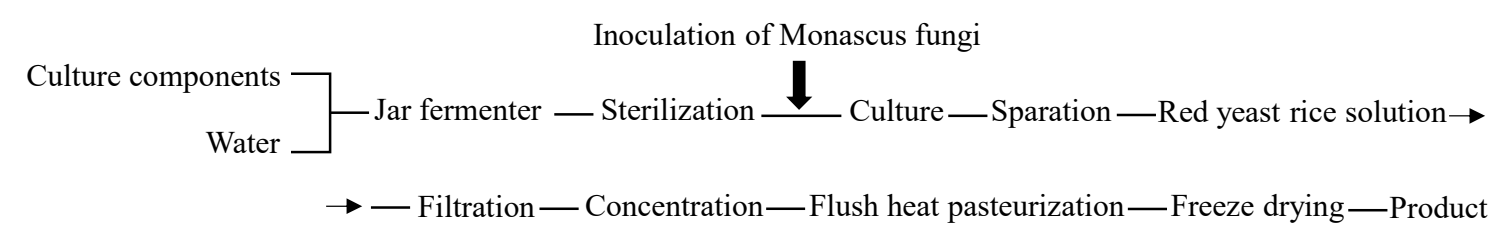

Figure 3. Solid-state/liquid-state culture method of red yeast rice. 


\subsection{Brewed Foods Produced Using Red Yeast Rice}

Red yeast rice has been widely used as a material for the production of anchu (Chinese red wine), tofunyu (fermented bean curd), and a coloring agent for foods or a preservative for meat in China and Taiwan.

The production technique for red Laojiu (Chinese alcohol beverage) originated in a Fijian Province in China and was introduced into Taiwan about 200 years ago. It is said to be the origin of the present-day Taiwanese red alcoholic beverage called Hon-ru-chu that is popular at festivals and wedding ceremonies [4].

Tofunyu, also called funyu or nyuhu, is a flavored food produced using mold proliferated on bean cakes which are salted and then matured by soaking in unrefined sake $[8,9]$. Fermented bean curd produced using red yeast rice is often called red funyu, and it is said to have originated the period about 1500 years ago in China. Red funyu is now produced in Jiangsu, Zhejiang, Sichuan, Hong Kong and Taiwan.

Brewed foods in East Asia were introduced to Japan sometime long ago. Tofuyo, a type of fermented bean curd (Figure 4), is a fermented food from Okinawa which is similar to red funyu in China and Taiwan. Tofuyo was introduced to Japan as "a fragrant and sweet/tasty food that improved digestive function and was effective in the treatment of various diseases" according to Gyozen Honzo (Edible plants of Okinawa), a book on dietary plants compiled in 1832 [4]. It was highly valued as a nutritional food and side dish in the 1800s. At present, tofuyo is produced by a novel method using aged sake, awamori (Okinawan distilled spirit).

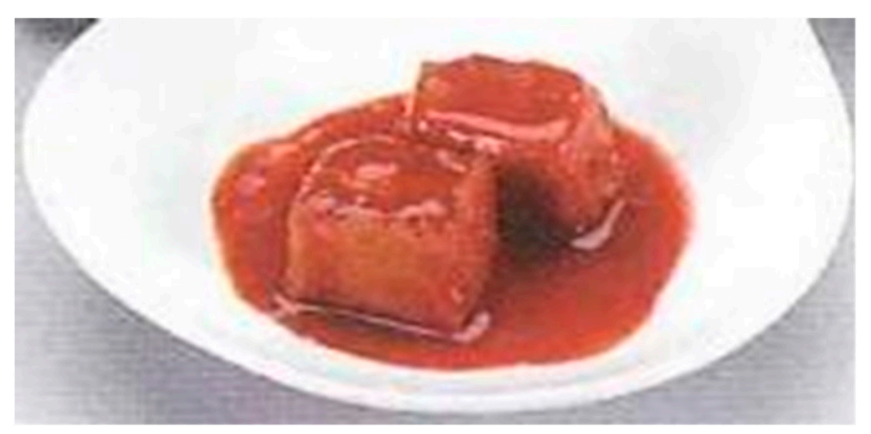

Figure 4. Tofuyo, a food that has been passed down the generations in Okinawa, Japan.

Funyu has been eaten for more than 1000 years in China. In Japan, it is prepared using miso produced with red yeast rice. In 1985, a Monuscus fungi was used to brew miso prepared by a traditional method, and it has been in use ever since [10].

Anchu has been produced in Okinawa since the 18th century, according to a written record and products list [11]. For many years, it has been produced in China using yeast rice on which Monascus fungi are proliferated. During 1850-1900, it is said, red rice and steamed red rice cakes wrapped in bamboo leaves were a traditional Okinawan food [12]. In China, a book called "Honzo-Jyushin", published in 1751, described a method for preparing red rice cake as follows: rice was mixed with red yeast rice and steamed, and the resultant red rice cake could be offered for food. Red rice is prepared by steaming rice grains after they have been mixed with red yeast rice. Red rice cakes are prepared by mixing red yeast rice soaked in sake and mashed in advance. The red yeast rice pigments mentioned above have been used in processed fish paste products (including crab-flavored fish paste cakes), jam, tomato ketchup, sweetened bean jam, stewed octopus, salmon roe, and processed meat products such as ham and sausage. In addition, red yeast rice pigments are used for coloring bread, confectionaries including rice confectionaries, and beverages, including amazake, and they are also widely used as pigments for foods in Asia and Europe [6,13]. 


\section{Polyketides and Other Metabolites Produced in Monascus Fungi}

\subsection{Polyketides Identified in Red Yeast Rice}

The compendium "Tiangong Kaiwu" describes fish meat as "generally spoilable, but its quality can be kept by smearing red yeast rice on its surface, even in hot conditions; no fly or maggot will approach, even 10 days later: red yeast rice is a truly miracle agent". This description indicates that red yeast rice has sterilizing or bacteriostatic action to prevent deterioration of fish meat caused by bacterial contamination (it may prevent fly swarming by other mechanisms). The custom to use red yeast rice in the preservation of foods is still used today; it is often used in the preservation of pork and chicken in Taiwan. Recent studies have demonstrated that M. purpureus produces substances with antibacterial activity against Bacillus, Streptococcus, and Pseudomonas species. Some of these substances are considered to be pigments. "Bencao Gangmu" (Compendium Materia Medica, vol. 25) written by Li Shizhen in 1590 describes a number of medicinal effects of red yeast rice, including that red yeast rice improves blood circulation, helps digestion, activates splenic function, cures diarrhea, heals bruises and injuries, enhances blood health, and protects a woman just after childbirth from blood stasis.

Red yeast rice pigments (polyketides) are called azaphilone pigments, and the following have been isolated and identified: monascin, ankaflavin, and monascinol (yellow pigments); rubropunctamine and monascorubramine (purple pigments); and rubropunctatin and monascorubrin (red pigments) (Figure 5) [4,7,14]. Furthermore, it has been reported that red yeast rice produces polyketide derivatives such as monascumic acid and $\gamma$-amino butyric acid (GABA) etc. [15-17]. Monascus pigments are known to have antibacterial activity and anti-cancer effects and GABA to have blood pressure-regulating effect [18-20]. It has also been reported that fermented rice bran with Monascus increases phenolic acid and enhances antioxidant activity [21,22]. In addition, organic acids, amino acids, sterols, decalin compound derivatives, flavonoids, lignans, coumarins, terpenoids, and polysaccharides are reported as components contained in red yeast rice [23].
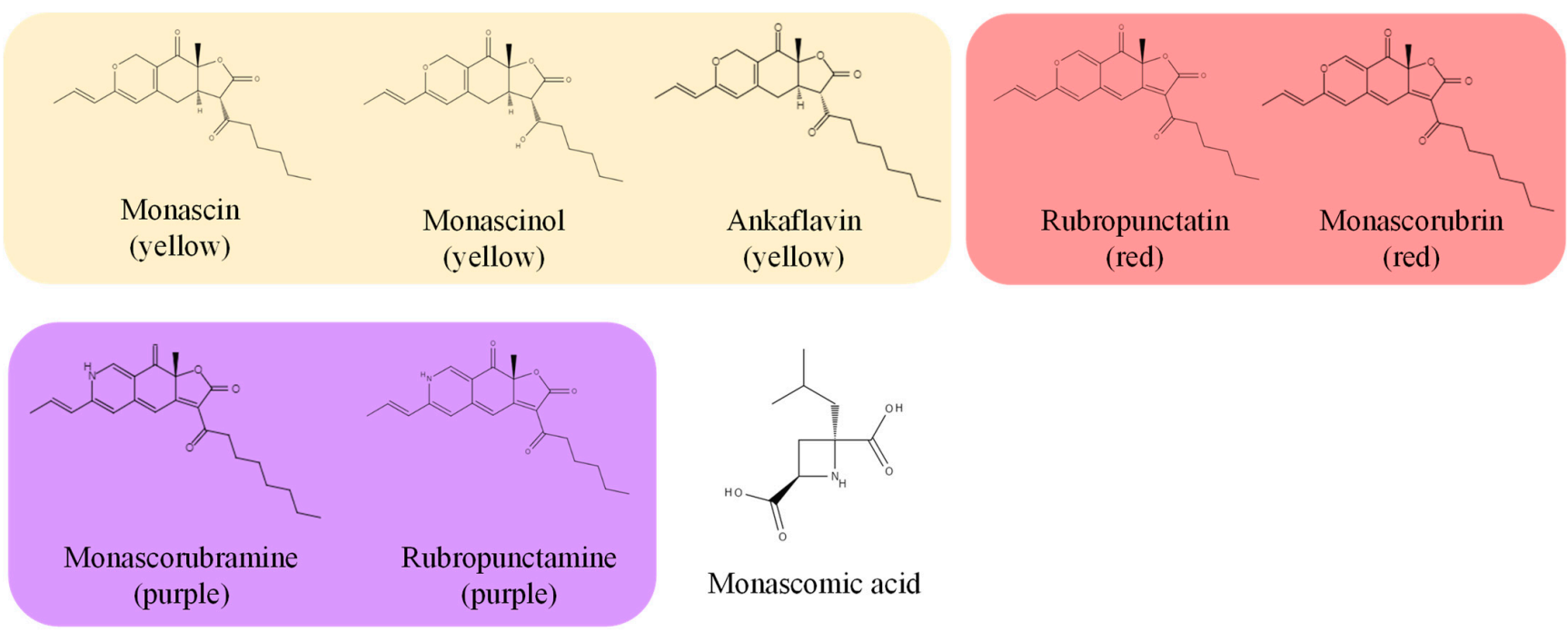

Figure 5. Major pigments (polyketides or azaphilone pigments) produced by Monascus fungi.

A potent inhibitor of cholesterol synthesis, monacolin K (lovastatin) was discovered in 1979 in a strain of Monascus by Endo et al. [1-3,24]. Other active substances with a similar structure to monacolin K have since been found (Figure 6) [25,26]. Monacolins have two forms, acid or lactone form, depending on the conditions of the solution, particularly the $\mathrm{pH}$ (Figure 7) [27]. 


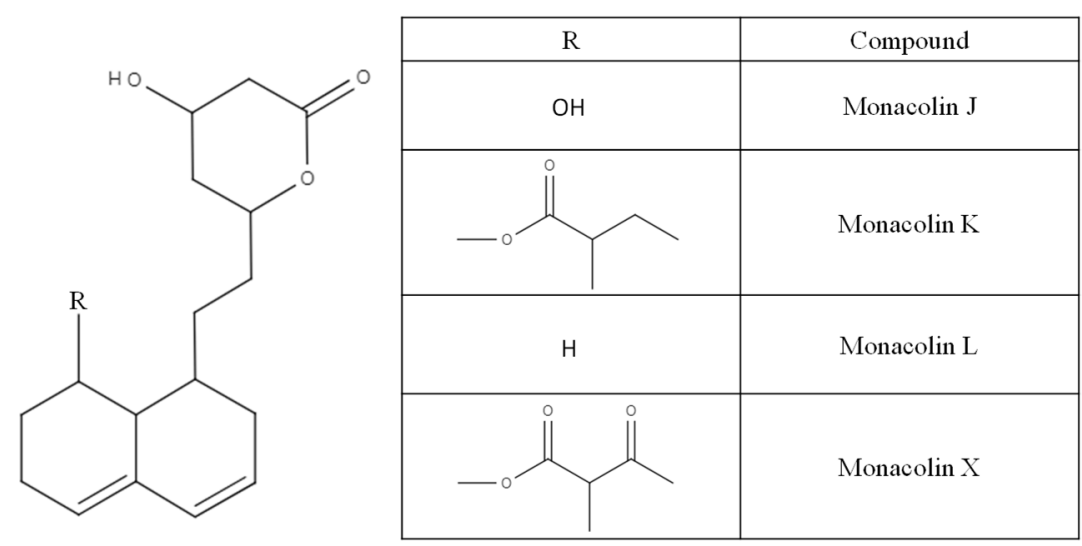

Figure 6. Monacolins (polyketides) produced by Monascus fungi.

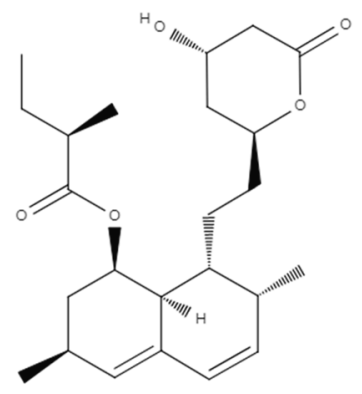

Monacolin K lacton

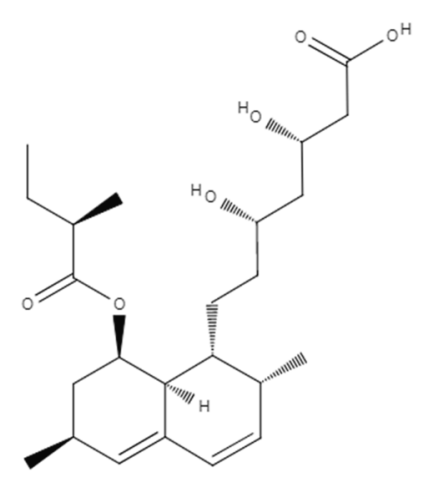

Monacolin K hydroxyl acid

Figure 7. Lactone and acid forms of monacolin K.

\subsection{Production of Metabolites, Including Representative Polyketides in Traditional Solid-State Fermentation}

Endo et al. also studied on red yeast rice that contained natural statins and favored by the Japanese in their diet. They examined color, taste and fragrance of various red yeast rice. Useful strains of Monascus fungi were bred, based on productivity of red yeast rice pigments and monacolin K. Recently, many attempts on breedings of Monascus strains and production conditions for efficient production of monacolin $\mathrm{K}$ have been reported [28]. The developed red yeast rice was produced using a traditional solid-state fermentation method [7].

M. pilosus is frequently used as a health food in Japan; we studied changes in its metabolite contents during growth. Steam-sterilized rice was inoculated with $M$. pilosus NITE BP-412, and a solid-state culture was started when the water content reached $42 \%$. The culture was grown for 43 days; a temperature of $30{ }^{\circ} \mathrm{C}$ was used for the first 4 days and then $22{ }^{\circ} \mathrm{C}$ for the remaining time; the change in the contents of metabolites was then analyzed. The change in appearance of the red yeast rice during the 43 days is shown in Figure 8 and demonstrates the gradual change in color of the rice from white to red. The change in monacolin $\mathrm{K}$ content in the red yeast rice during fermentation was measured: The contents of both the lactone and acid form time-dependently increased (Figure 9). The contents of three azaphilone pigments (monascin, monascinol, and rubropunctamine) in red yeast rice were measured: The monascin content reached its peak 20 days after the start of the culture. Monascinol reached its peak 30 days after the start of the culture, and rubropunctamine began to increase about 10 days after the start of the culture and reached its peak at about 30 days. All pigments plateaued after they peaked (Figure 10). The time course change in the contents of two amino acids (GABA and monascumic acid) in red yeast rice during fermentation was also examined. The GABA content increased, with the peak occurring about day 20 , and the level gradually decreased thereafter. The 
monascumic acid content also increased, with the peak on day 20, and the level plateaued thereafter (Figure 11).

\section{Culture period}

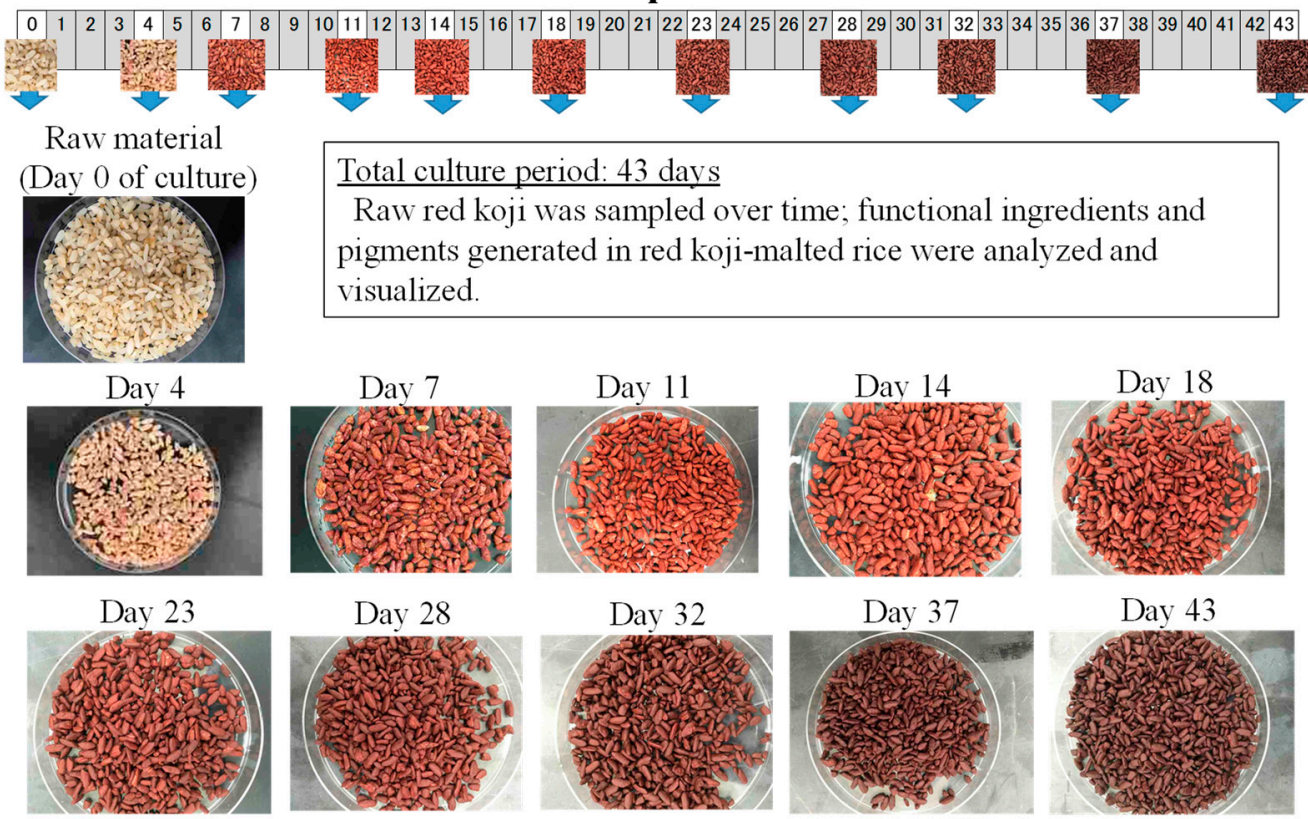

Figure 8. Time course change in appearance of red koji, which reddens during fermentation.
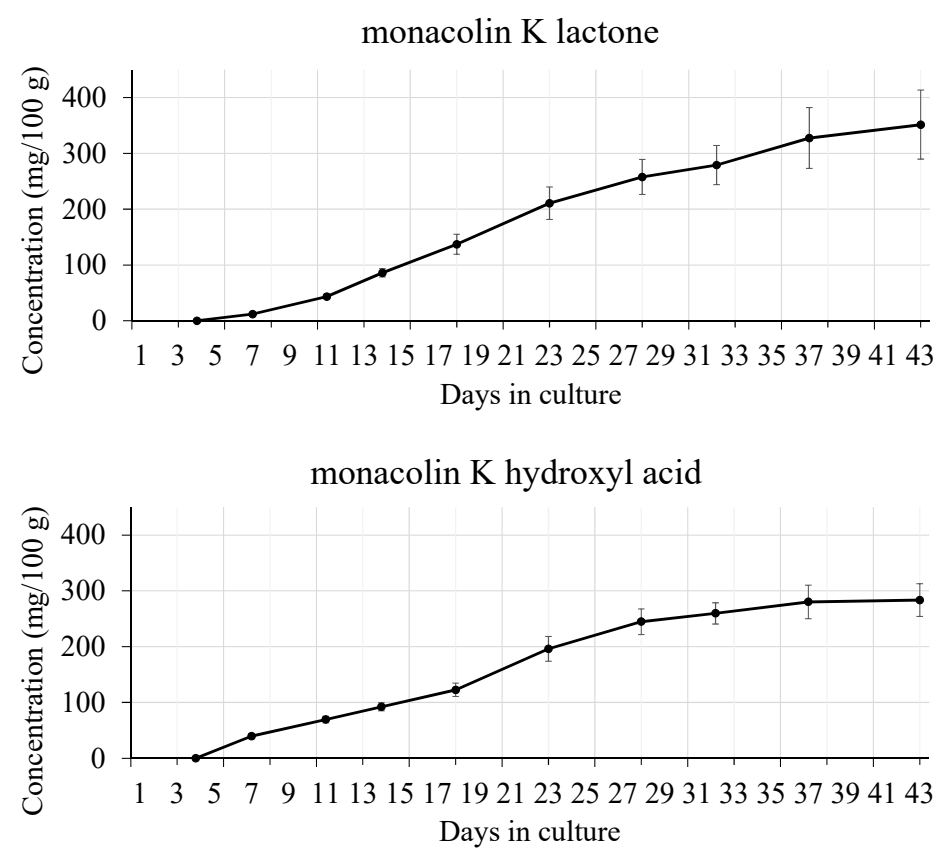

Figure 9. Time course change in the content of lactone form and acid form of monacolin $\mathrm{K}$ in red yeast rice during fermentation, quantified using the method specified by the Korea Food and Drug Administration (KFDA) [29]. 

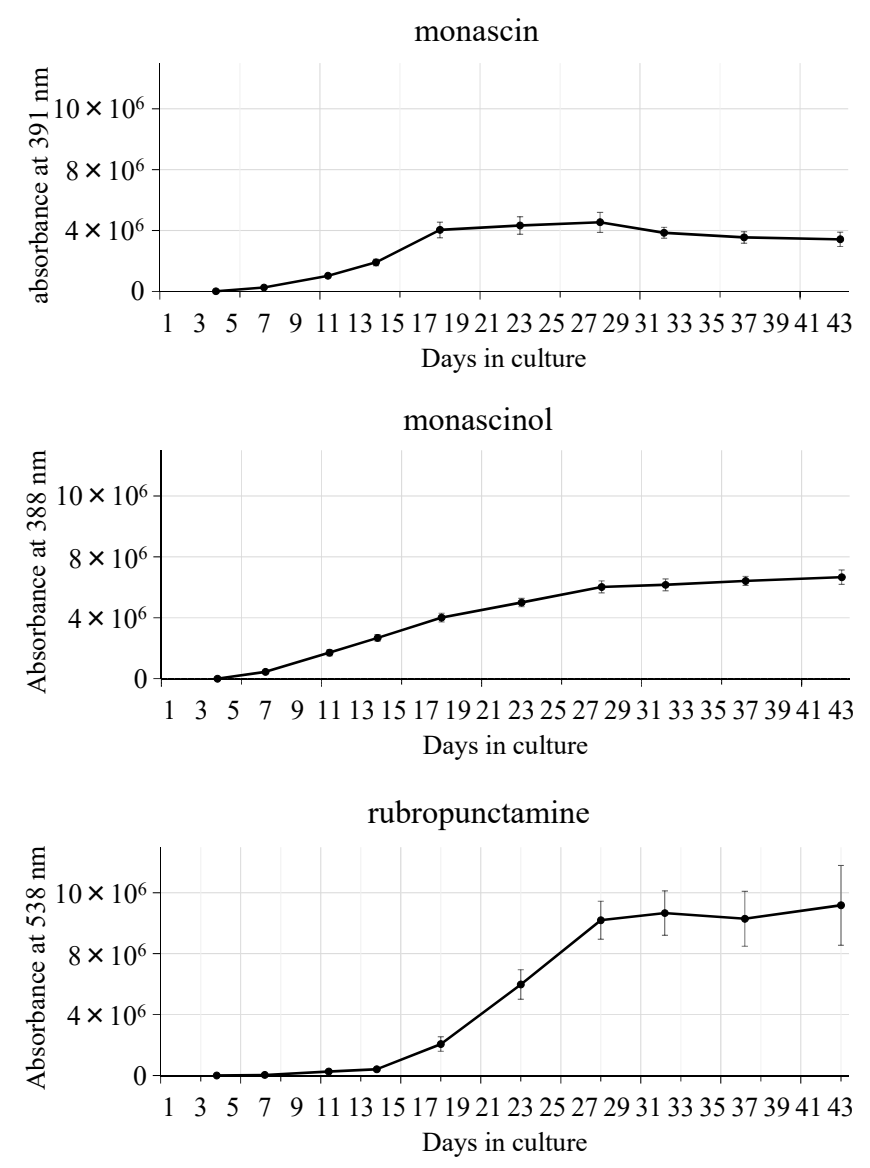

Figure 10. Time course change in the contents of 3 azaphilone pigments in red yeast rice during fermentation, quantified according to the reference method [30].
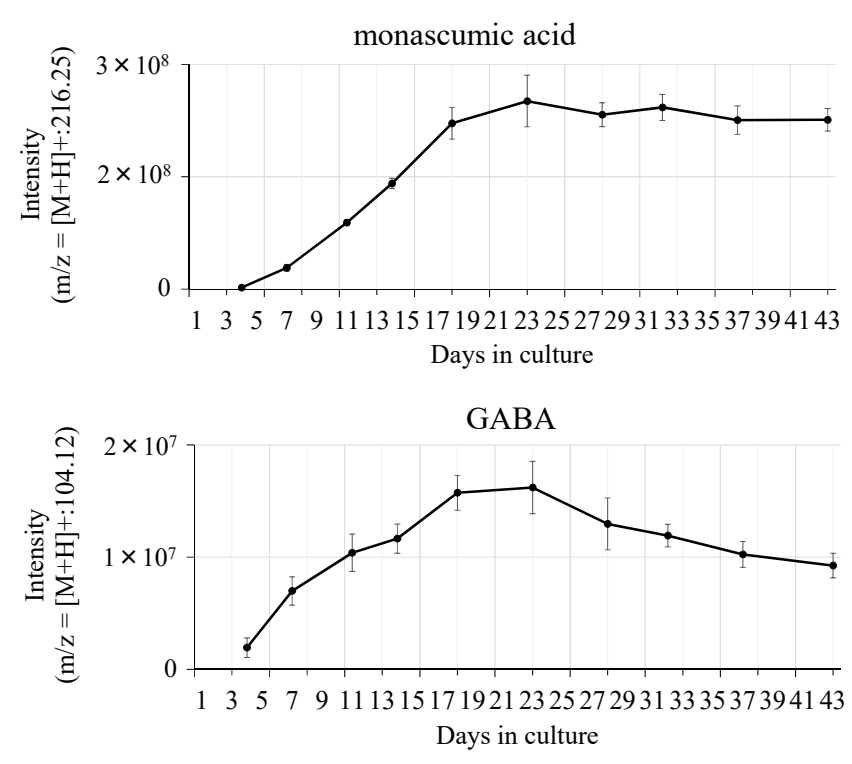

Figure 11. Time course change in the contents of 2 amino acids (GABA and monascumic acid) in red yeast rice during fermentation, quantified by liquid chromatography-mass spectrometry (LC-MS) [16,17].

The results suggest that $M$. pilosus fought against foreign enemies, utilizing monascumic acid as its antibacterial activity in the first half of their growth and monacolin $\mathrm{K}$ with its cholesterol synthesis inhibiting activity in the second half of their growth. GABA could be used as a nitrogen source in the second half of growth, when nutrients become deficient; 
however, we suggest GABA was mainly used to fight against foreign enemies since it decreased in the middle of the second half of the growth phase. Based on these findings, we expect further improvements to traditional solid-state fermentation methods will lead to the development of useful materials in the production of red yeast rice.

\section{Effectiveness of Red Yeast Rice: Its Functional Ingredients and Physiological Actions on Lipid Metabolism and the Circulatory System}

\subsection{Monacolins and Their Cholesterol Lowering Effect}

Monacolins are inhibitors of 3-hydroxy-3-methylglutaryl-CoA (HMG-CoA) reductase, a key enzyme regulating hepatic cholesterol synthesis, and exert potent serum cholesterol lowering effects (Figure 12).

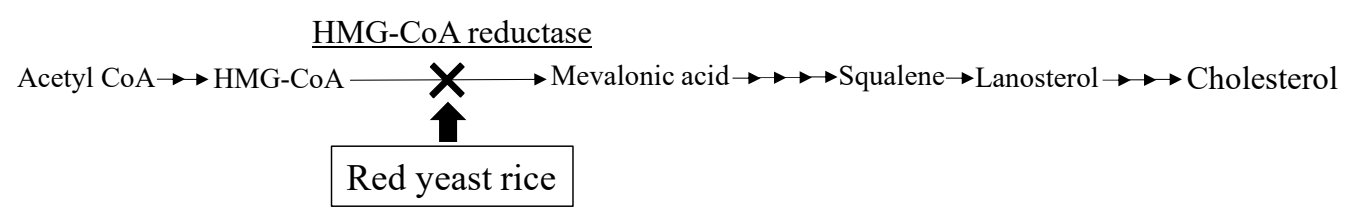

Figure 12. Biosynthetic pathway of cholesterol synthesis and the action of red yeast rice in it.

Lovastatin and its analogs (including their derivatives) have been used as medicines since 1987 by Japanese and foreign pharmaceutical companies. Statins inhibit HMG-CoA reductase, lower hepatic cholesterol biosynthesis and elevate the expression of hepatic LDL-receptors to maintain cholesterol homeostasis, which in turn enhances uptake of LDLcholesterol into the liver and decreases blood cholesterol levels [31-33]. LDL-cholesterol is known as bad cholesterol because it is involved in atheroma formation and causes atherosclerosis. Since statins have excellent LDL-cholesterol-lowering effects, they are used as first-line drugs for patients with hypercholesterolemia, and several world-wide largescale clinical trials have been conducted on statins. These trials have demonstrated not only their efficacy on cardiovascular disease such as cardiac infarction and cerebral stroke but also various actions such as potential preventive action on bone fracture. Statins prevented cardiovascular events by $25-30 \%$ in clinical trials assessing primary and secondary preventive effects on coronary artery disease, indicating that they are essential medicines for patients with cardiovascular disease [34,35]. Since it has been reported recently that statins show pleiotropic effects, such as a restorative effect on vascular endothelial functions and anti-inflammatory effects, an accumulation of evidence for their therapeutic and preventive effects on various diseases is expected [36,37].

Clinical studies in Japan have also been conducted on processed food containing red yeast rice produced using the traditional solid-state fermentation described in Section 2.2 [38-40].

In normal healthy volunteers with plasma LDL-cholesterol levels of $120 \mathrm{mg} / \mathrm{dL}$ or higher, long-term feeding of a processed food product containing 100 or $200 \mathrm{mg}$ of red yeast rice produced by solid-state fermentation significantly lowered plasma levels of LDL-cholesterol and total cholesterol compared to those in volunteers fed the placebo at 2-8 weeks after starting the feeding. The lowered levels returned to the initial values after the end of red yeast rice intake. No significant differences in HDL-cholesterol and triglyceride levels and safety evaluation items among the 3 groups were found (Figure 13) [38]. In addition, in patients with hyperlipidemia where it was not improved during 1-monthdiet therapy according to an NCEP panel, repetitive intake of a processed food product containing red yeast rice at $1 \mathrm{~g}$ /day significantly lowered levels of total cholesterol and LDL-cholesterol by about 10\% [40]. Reports of clinical trials in Europe also show significant improvements in hypercholesterolemia by ingestion of red yeast rice containing 3-10 mg of monacolin K $[41,42]$. 


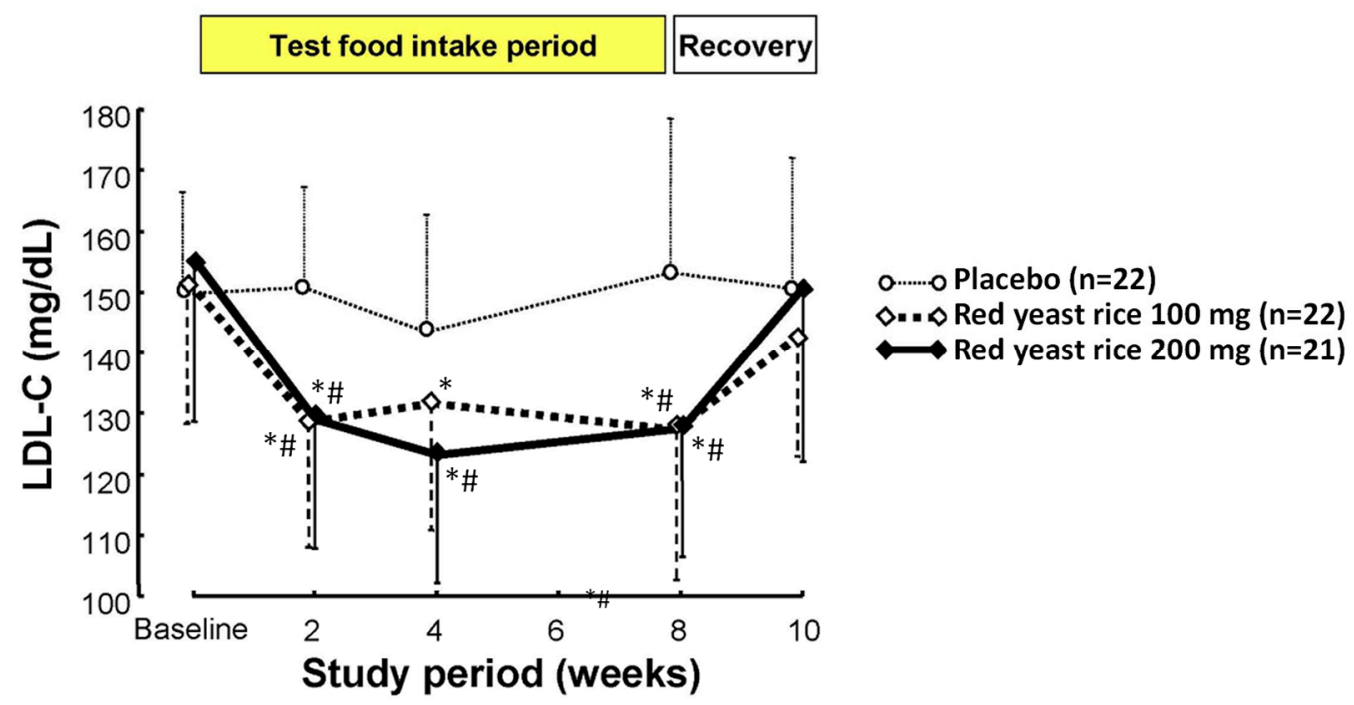

Figure 13. Effect of intake of red yeast rice produced by solid-state fermentation in normal healthy volunteers whose plasma cholesterol levels were $120 \mathrm{mg} / \mathrm{dL}$ or higher. Each bar indicates the mean \pm standard deviation. *: Significant difference from start of ingestion $(p<0.05$, paired ANOVA). \#: Significantly different from the placebo group $(p<0.05$, multiple comparison using Bonferroni).

Recently, we compared the pharmacokinetics of monacolin $\mathrm{K}$ in blood after oral administration of purified monacolin $\mathrm{K}$ (lactone form, 99\% purity) and red yeast rice produced by solid-state fermentation in male SD rats (7 weeks old). Most of the monacolin $\mathrm{K}$ in the plasma was detected in its acid form: both in the monacolin K-administered group and the red yeast rice -administered group. Surprisingly, the maximum level (C max) and area under curve (AUC) of plasma monacolin K concentration 4 hours after administration were several times higher in the red yeast rice-administered group than in the purified monacolin K-administered group (Figure 14, Table 3). These results suggest that red yeast rice contains ingredients that enhance the absorption of monacolin $\mathrm{K}$ into blood. The medicinal benefit of red yeast rice is considered to be different to that of monacolin $\mathrm{K}$ alone. Furthermore, our recent experiments show that monacolin L, monascinol, and monascodilone also have HMG-CoA reductase activity. Since red yeast rice contains various ingredients, synergistic effects are expected.
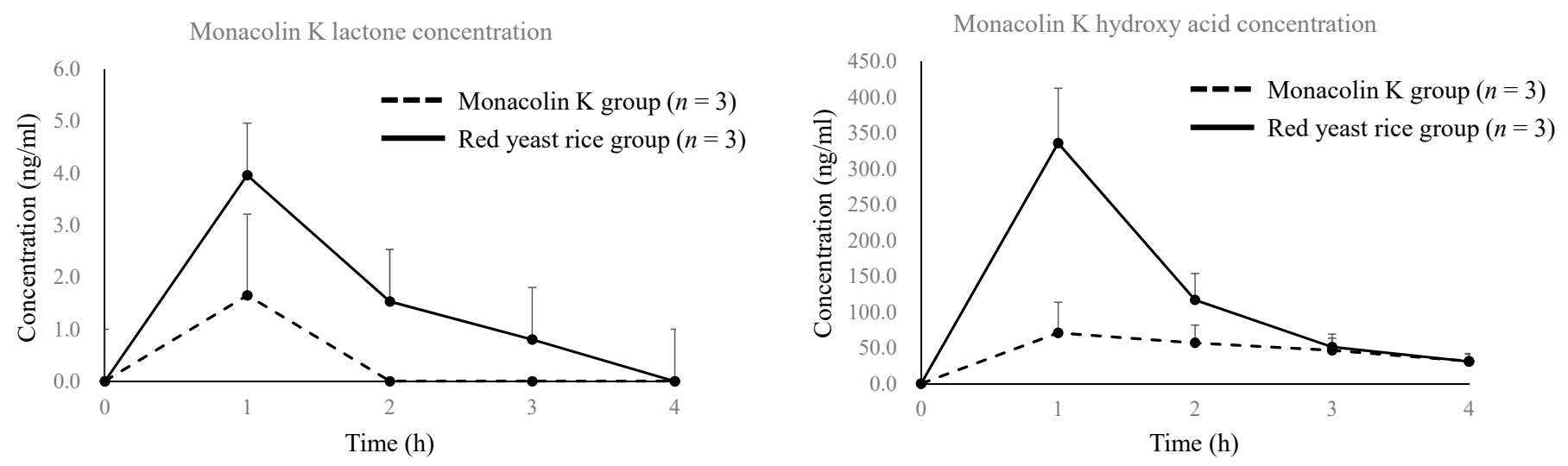

Figure 14. Plasma concentrations of lactone form and acid form of monacolin $\mathrm{K}$ after single administration of purified monacolin $\mathrm{K}$ or red yeast rice ( $40 \mathrm{mg} / \mathrm{kg}$ monacolin $\mathrm{K}$ or dose of red yeast rice equivalent to $40 \mathrm{mg} / \mathrm{kg}$ monacolin $\mathrm{K}$ ) in male $\mathrm{SD}$ rats (7 weeks old). Each bar indicates the mean \pm standard deviation, quantified according to the reference method [43]. 
Table 3. Pharmacokinetic parameters of the lactone form and acid form of monacolin $\mathrm{K}$ in plasma after single administration of purified monacolin $\mathrm{K}$ or red yeast rice ( $40 \mathrm{mg} / \mathrm{kg}$ monacolin $\mathrm{K}$ or dose of red yeast rice equivalent to $40 \mathrm{mg} / \mathrm{kg}$ monacolin $\mathrm{K}$ ). Peak analysis was performed according to the reference method [44].

\begin{tabular}{|c|c|c|c|c|c|c|c|c|c|c|c|}
\hline \multicolumn{6}{|c|}{ PK Parameter of Monacolin K Lactone } & \multicolumn{6}{|c|}{ PK Parameter Of Monacolin K Hydroxy Acid } \\
\hline \multicolumn{6}{|c|}{ Monacolin K Administration Group } & \multicolumn{6}{|c|}{ Monacolin K Administration Group } \\
\hline PK Parameter & 101 & 102 & 103 & Mean & S.D. & PK Parameter & 101 & 102 & 103 & Mean & S.D. \\
\hline$t_{1 / 2}(h)$ & N.C. & N.C. & N.C. & - & - & $t_{1 / 2}(h)$ & 2.7 & 1.7 & N.C. & 2.2 & - \\
\hline $\mathrm{T}_{\max }(\mathrm{h})$ & 1.0 & 1.0 & N.C. & 1.0 & - & $\mathrm{T}_{\max }(\mathrm{h})$ & 1.0 & 1.0 & 2.0 & 1.3 & 0.6 \\
\hline $\mathrm{C}_{\max }(\mathrm{ng} / \mathrm{mL})$ & 3.11 & 1.85 & N.C. & 2.48 & - & $\mathrm{C}_{\max }(\mathrm{ng} / \mathrm{mL})$ & 72.6 & 113 & 55.5 & 80.4 & 29.5 \\
\hline $\mathrm{AUC}_{0-4 \mathrm{~h}}(\mathrm{ng} \cdot \mathrm{h} / \mathrm{mL})$ & 3.11 & 1.85 & N.C. & 2.48 & - & $\mathrm{AUC}_{0-4 \mathrm{~h}}(\mathrm{ng} \cdot \mathrm{h} / \mathrm{mL})$ & 143 & 274 & 153 & 190 & 73 \\
\hline \multicolumn{6}{|c|}{ Red yeast rice administration group } & \multicolumn{6}{|c|}{ Red yeast rice administration group } \\
\hline PK parameter & 201 & 202 & 203 & Mean & S.D. & PK parameter & 201 & 202 & 203 & Mean & S.D. \\
\hline $\mathrm{t}_{1 / 2}(\mathrm{~h})$ & N.C. & N.C. & N.C. & - & - & $t_{1 / 2}(h)$ & 1.4 & 1.1 & 0.98 & 1.1 & 0.2 \\
\hline $\mathrm{T}_{\max }(\mathrm{h})$ & 1.0 & 1.0 & 1.0 & 1.0 & 0.0 & $\mathrm{~T}_{\max }(\mathrm{h})$ & 1.0 & 1.0 & 1.0 & 1.0 & 0.0 \\
\hline $\mathrm{C}_{\max }(\mathrm{ng} / \mathrm{mL})$ & 4.32 & 4.03 & 3.54 & 3.96 & 0.39 & $\mathrm{C}_{\max }(\mathrm{ng} / \mathrm{mL})$ & 254 & 349 & 406 & 336 & 77 \\
\hline $\mathrm{AUC}_{0-4 \mathrm{~h}}(\mathrm{ng} \cdot \mathrm{h} / \mathrm{mL})$ & 7.20 & 5.22 & 6.46 & 6.29 & 1.00 & $\mathrm{AUC}_{0-4 \mathrm{~h}}(\mathrm{ng} \cdot \mathrm{h} / \mathrm{mL})$ & 457 & 470 & 632 & 520 & 98 \\
\hline
\end{tabular}

\subsection{Improving Effects of Red Yeast Rice on Chyle in Blood and Increased Viscosity Caused by Hyperlipidemia}

In general, continuous intake of a high-fat or high-cholesterol diet causes hyperlipidemia and the blood develops chyle, a white cloudy substance which mainly consists of lipoproteins. Chylemia is regarded as a risk factor for circulatory diseases, and its suppression is considered to be important for risk reduction. Recently, we conducted an experiment in which male Japanese white rabbits (10-12 weeks old) were fed a diet containing $0.25 \%$ cholesterol for 2 weeks to produce chylemia. The rabbits were then allocated into a red yeast rice-treated group, in which powdered red yeast rice was orally administered for 3 weeks or non-treated group. Blood samples were collected from both groups for plasma biochemical examinations and measurement of plasma turbidity. Macroscopic observations showed lower plasma turbidity in the red yeast rice-treated group compared with the non-treated group, and biochemical analysis revealed a statistically significant increase in light transmittance (Figure 15) and decrease in plasma total cholesterol levels in the red yeast rice-treated group compared with the non-treated group.
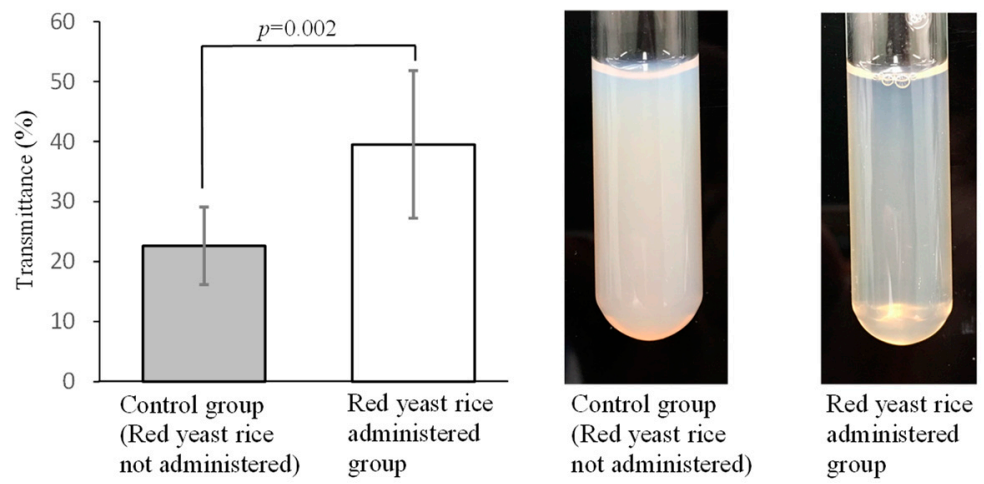

Figure 15. Difference in transmittance of plasma between red yeast rice-treated (2 weeks) and non-treated groups of male Japanese white rabbits (10-12 weeks old) fed a high-cholesterol diet. A decrease in turbidity in the red yeast rice-treated group is apparent. Each bar indicates the mean \pm standard deviation. Significant differences were tested by Student's $t$-test. Plasma cloudiness was evaluated by measuring the transmittance at a wavelength of $660 \mathrm{~nm}$ using an absorptiometer.

It has also been reported that hyperlipidemia induces metabolic abnormality of lipoproteins and an increase in plasma viscosity, which in turn elevates the risk of cardiac 
and cerebrovascular diseases [45-47]. Lovastatin or ezetimibe, anti-hyperlipidemic drugs, have been reported to decrease plasma viscosity $[48,49]$. In our study, male Japanese white rabbits (14 weeks old) were fed a diet containing $0.25 \%$ cholesterol (HC diet) for 3 months as a hyperlipidemic animal model. During the 3-month feeding period, the control group was fed the HC diet alone, and the red yeast rice-treated group was fed the $\mathrm{HC}$ diet with red yeast rice at $500 \mathrm{mg} / \mathrm{kg}$ body weight. Blood biochemical analyses, performed during the feeding period, included measurements of plasma turbidity, viscosity and cholesterol content of lipoproteins. Plasma turbidity was improved, and total cholesterol and LDL-cholesterol plasma levels were reduced in the red yeast rice-treated group between months 1-3 of the experimental period, when compared to the control group. Furthermore, 3 months after the start of administration, the low-density cholesterol content of lipoproteins and plasma viscosity were still lower in the red yeast rice-treated group compared with the control group (Figure 16). In particular, the cholesterol contents in chylomicrons and VLDL were significantly lowered (Figure 17). These results indicate that ingredients in red yeast rice suppressed the increase in plasma viscosity by decreasing the content of large (low-density) lipoproteins through a reduction in VLDL release and clearance of chylomicrons.

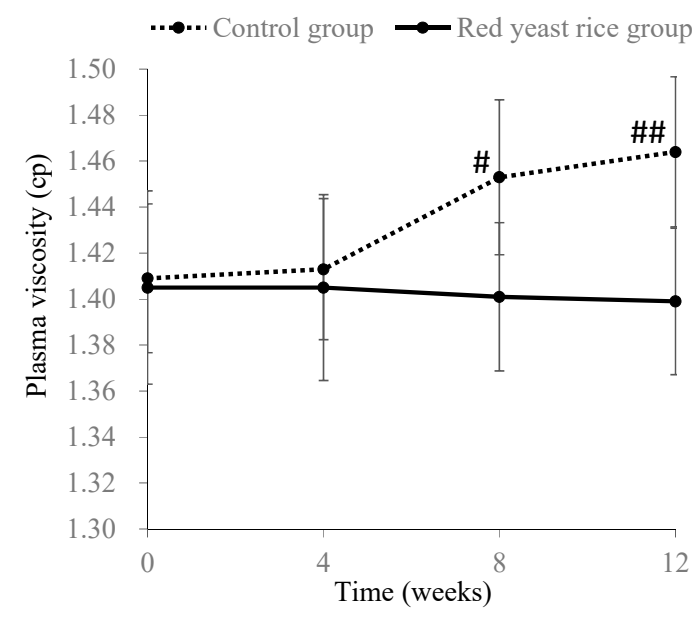

Figure 16. Time course changes in plasma viscosity in a control group and a red yeast rice-treated group in hypercholesterolemic model rabbits. Each bar indicates the mean \pm standard deviation. Significant differences between control group and red yeast group were tested by Student's $t$-test (\#: $p<0.05$, \#\#: $p<0.01$ ). Plasma viscosity was measured using a plate and cone viscometer according to the reference method [50].
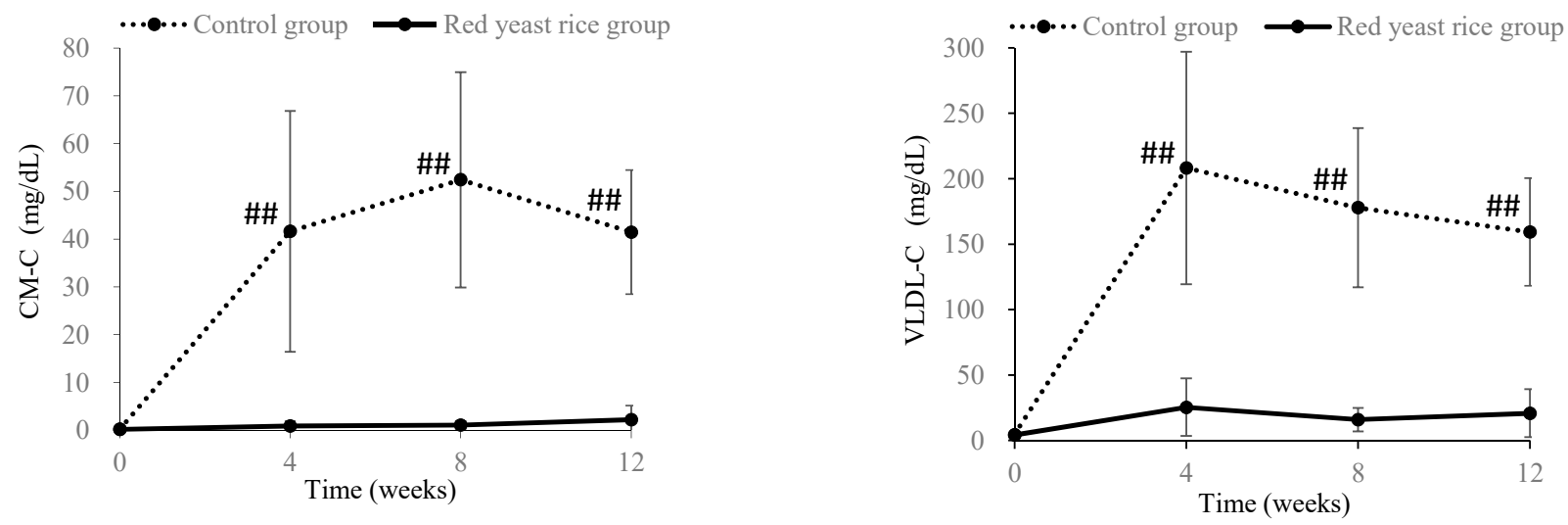

Figure 17. Time course change in contents of cholesterol in plasma low-density lipoproteins (chylomicron-cholesterol and VLDL-cholesterol) obtained from a red yeast rice-treated and control groups of hypercholesteremic model rabbits. Each bar indicates the mean \pm standard deviation. Significant differences between control group and red yeast group were tested by Student's $t$-test (\#\#: $p$ <.01). Plasma lipoprotein cholesterol was quantified according to the reference method [51]. 
Red yeast rice has the potential to prevent vascular disease associated with hyperlipidemia or reduce the risk for these diseases, through suppression of atheroma formation and improve blood fluidity, by lowering levels of chylomicrons and VLDL, lipoproteins that are the main components of plasma chyle.

\subsection{Promising Effects of Ingredients in Red Yeast Rice on Risk Reduction for Circulatory Diseases}

The evidence presented above suggests red yeast rice could reduce the risk of vascular diseases associated with hyperlipidemia; however, red yeast rice also contain statins and various other ingredients which are effective in the circulatory system. Table 4 summarizes the potential effects of monacolin K (lovastatin) on circulatory diseases, including cardiac disease. There has been a lot of evidence reported on the favorable actions of statins, including their HMG-CoA reductase inhibiting activity which suppresses atheroma formation in atherosclerosis [52-54], improving effects on blood circulation [55,56], and pleiotropic effects on nitric oxide (NO) production which plays a pivotal role in homeostasis of the cardiovascular system and the NO synthetase-NO pathway [57-59]. Effects of lovastatin on atherogenic signaling cascades [60] have also been reported [61-63]. There have also been similar favorable reports of red yeast rice extracts, such as upregulation of constitutive NO synthetase expression, the increase in plasma levels of nitric oxides and improvement of abnormal hemorheology in an atherosclerotic rat model induced by high-cholesterol diet feeding [64]. These effects are considered to be beneficial in the prevention of circulatory diseases and improvement in blood circulation.

Table 4. Actions of monacolin K (lovastatin) on circulatory system and related fields.

\begin{tabular}{|c|c|c|c|}
\hline Evaluation Target & Study Subjects or Study Materials & Effect of Monacolin K & Ref. \\
\hline \multirow{3}{*}{ Atheroma formation } & Rabbits fed on a high-lipid diet & $\begin{array}{c}\text { Decrease in number of plaques in the aorta and } \\
\text { lung artery }\end{array}$ & {$[52]$} \\
\hline & Patients with hypercholesterolemia & $\begin{array}{l}\text { Inhibition of platelet aggregation, macrophage foam } \\
\text { cell formation and LDL oxidation }\end{array}$ & [53] \\
\hline & $\begin{array}{l}\text { Human umbilical vein endothelial } \\
\text { cells (HUVECs) }\end{array}$ & Inhibition of NF-KB activation by CRP & [54] \\
\hline \multirow[b]{2}{*}{ Blood circulation } & Hypertensive model mice & Increase in renal blood flow & [55] \\
\hline & $\begin{array}{l}\text { Several studies using } \\
\text { experimental animals }\end{array}$ & $\begin{array}{l}\text { Increase in cerebral blood flow and cerebral } \\
\text { vasomotor response }\end{array}$ & [56] \\
\hline \multirow{3}{*}{$\begin{array}{l}\text { NOS signaling } \\
\text { pathway }\end{array}$} & Cardiac myocytes & $\begin{array}{l}\text { Increase of IL-1 induced production of nitrite } \\
\text { (Increase in NOS expression and NO production } \\
\text { mediated by Rho inhibition) }\end{array}$ & {$[61]$} \\
\hline & Squamous epithelial cancer cells & Induction of expression of Rho family proteins & [62] \\
\hline & $\begin{array}{l}\text { Mesenchymal stem cells derived from } \\
\text { rat bone marrow }\end{array}$ & $\begin{array}{c}\text { Activation (phosphorylation) of AI3K/Akt pathway } \\
\text { and MEK } 1 / 2 \text { pathway }\end{array}$ & {$[63]$} \\
\hline
\end{tabular}

Ingredients that are known to be effective in red yeast rice, other than statins, include GABA, which exerts a hypotensive effect through reduction of adrenergic vasoconstriction by its suppressive effect on the release of sympathetic nerve transmitters mediated by presynaptic GABA receptors $[65,66]$. In addition, GABA promotes sodium excretion from the kidneys and suppresses increases in blood pressure $[67,68]$.

Oxidative stress is also regarded as a therapeutic target related to atherosclerosis. Reactive oxygen inactivates NO and at the same time damages vascular endothelial cells and reduces NO production. It has also been suggested that plasma LDL suppresses NOS activity in vascular endothelial cells by hydroxyl radicals and the like, thereby reducing NO production and promoting arteriosclerosis. [69,70]. Lovastatin inhibits oxidation of LDL, and this improves the vascular endothelial function (vasoconstrictor reaction) in hyperlipidemia, and in particular, the combined use of an antioxidant can significantly 
improve the function $[64,71]$. Antioxidant activity has also been reported in red yeast rice pigments [72,73]: monascin and ankaflavin suppressed LDL-cholesterol oxidation [74]. In addition, a previous clinical study reported that a red yeast rice extract reduced plasma levels of oxidized LDL, an index of oxidative stress, and lipoprotein-associated phospholipase $\mathrm{A}_{2}$ activity [75]. Red yeast rice made from brown rice, black rice, and red rice has also been shown to improve vascular endothelial function with increased NO production [76].

Monascin and ankaflavin are reported to act as the agonist for peroxisome proliferatoractivated receptors (PPARs), e.g., PPAR $\alpha$ [77]. PPARs that are involved in metabolism of carbohydrates, lipids, and energy are also closely involved in development of life-style related diseases, such as obesity and atherosclerosis. PPAR $\alpha$ agonists (fibrates) have been clinically used as antihyperlipidemic drugs.

Vascular function can be improved by increasing NO, suppressing oxidative stress, hypertension, obesity, etc. [78-80]. It is expected that ingredients contained in red yeast rice, such as monacolin K (lovastatin), GABA, and red yeast rice pigments (azaphilone pigments) exert synergic or additive effects to lower the risk for atherosclerosis and other circulatory diseases (Figure 18).

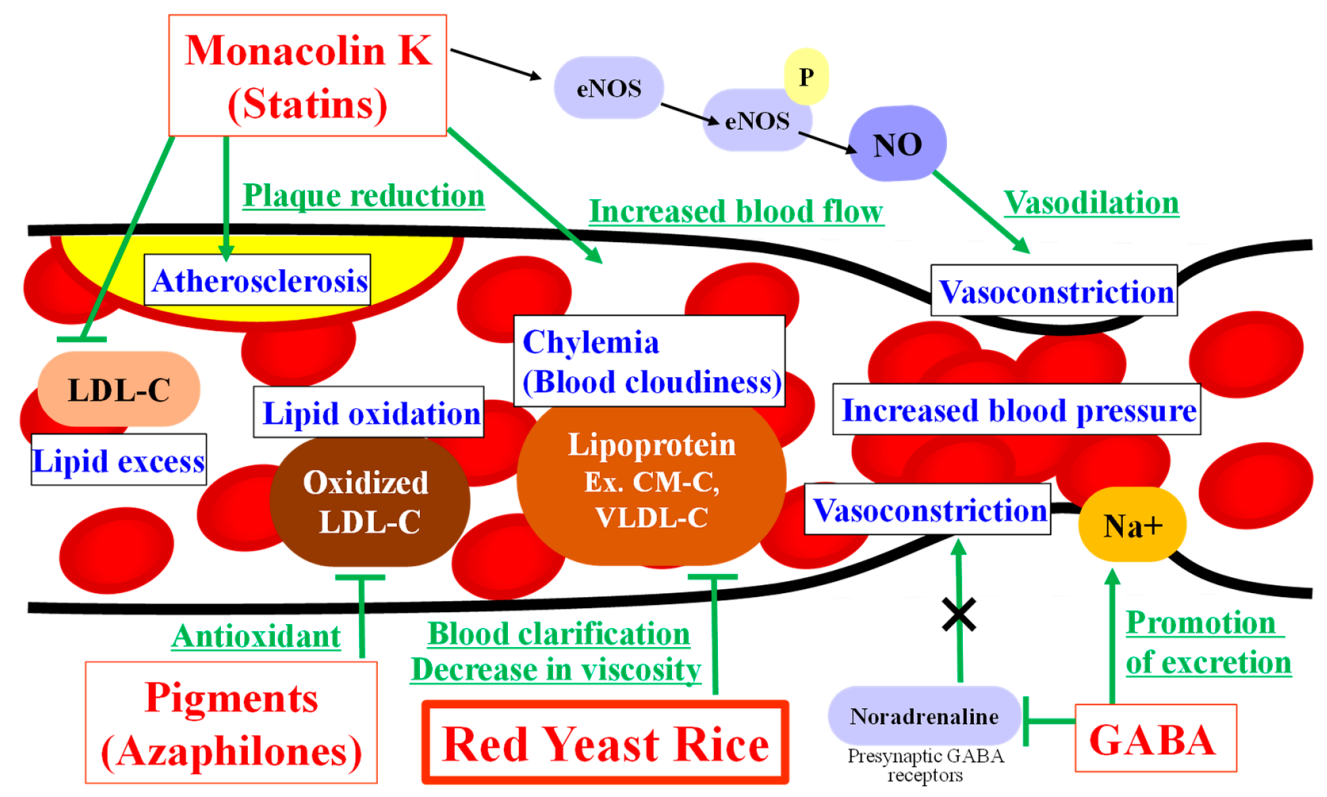

Figure 18. Expected effect on the circulatory system of red yeast rice and its components.

\section{Safety of Red Yeast Rice}

Red yeast rice produced properly by traditional solid-state fermentation using Monascus fungi is considered to be safe for food use; not only because of its long history within the Asian diet but also because red yeast rice manufacturers have made every effort to ensure its safety using various tests, including mutagenicity, acute toxicity, and chronic toxicity tests. The processed food containing red yeast rice used in a previous clinical trial has been commercially used for more than 20 years in Japan, and no problematic cases have been reported from a safety point of view. Furthermore, since red yeast rice pigments industrially produced with Monascus fungi are approved as food additives, their safety is institutionally secured by various toxicity tests based on legal standards [7].

Of the Monascus fungi, M. pilosus, M. ruber, and M. purpureus are mainly used for food in Japan, Taiwan, and China, respectively. It has been reported that the gene encoding citrinin, a mycotoxin causing renal toxicity, is functional in some strains of M. purpureus and $M$. ruber $[81,82]$. We recently conducted whole-genome analysis of these three strains of Monascus fungi using a next generation sequencer and demonstrated that M. pilosus was unable to generate citrinin [83]. This finding indicates that, of the three commercially used Monascus fungi, only M. pilosus does not generate the mycotoxin, citrinin. Consequently, 
based on its long history and the results of recent studies, red yeast rice is a safe material as long as its prepared and used properly.

\section{Conclusions}

In paragraph 1, we introduced that red yeast rice has been a prized medicinal food in East Asia for about 1500 years, and has been widely used as a food and pigment in recent years. In paragraph 2, we introduced the metabolites of red yeast rice, mainly polyketide compounds. These ingredients vary depending on the type of Monascus and the culture/manufacturing method, but even today, red yeast rice produced by tradi-tional solid fermentation is widely used as a health food material and we showed the changes in the amounts of the typical components during the solid-state fermentation process. In the future, it is expected to develop red yeast rice materials that has more beneficial balances of ingredients in the safe ancient manufacturing method.

In Section 3, we introduced mainly introduced the findings on the usefulness of red yeast rice on lipid metabolism and circulatory system. The data from our animal studies described in Sections 3.1 and 3.2 suggest that in addition to monacolin $\mathrm{K}$, other compo-nents of red yeast rice may improve lipid metabolism. However, it is a future issue to conduct experiments with more appropriate controls to clarify in more detail whether the effects other than LDL-cholesterol lowering effect are due to the red yeast rice component alone or the combination of monacolin $\mathrm{K}$ and red yeast rice components. In addition, the findings of the effects of statins, pigments, and GABA on the circulatory system as typical components were introduced in Section 3.3, but the involvement of various components reported to contain in red yeast rice, such as sterols, decalin compounds, the derivatives, flavonoids, lignans, coumarins, terpenoids, polysaccha-rides and phenolic acids is unknown [23]. Further elucidations of the relationship be-tween each of components of red yeast rice are expected.

Here, we introduced the typical lipid metabolism and effects of monacolin K (lovastatin) on the lipid metabolism and circulatory system, but recent reports have shown that monacolin $\mathrm{K}$ is also useful for the treatment of neurological disorders, cancer, etc. and these studies are also being highlighted [84]. Furthermore, various functionalities such as anti-cancer effect, neuroprotective effect, liver protective effect, osteoporosis improving effect, anti-diabetic effect, anti-obesity effect, anti-fatigue ef-fect, and anti-inflammatory effect have been reported for red yeast rice [23]. It has been suggested that various components other than monacolin $\mathrm{K}$ are involved in these actions in a complex manner. In the future, it is expected that evidence will be accumulated and will help improve the quality of life in a wide range beyond the prevention of lifestyle-related diseases.

In conclusion, red yeast rice is promising as a functional food material that can maintain and improve health in addition to preventing lifestyle related diseases. As a food material, it has high medicinal properties, various functions and safety. It is expected that new values will be elucidated in the future.

Author Contributions: Conceptualization, H.F.; investigation and resources, Y.H., T.H. (Tomohiro Hisano) and K.A.; data curation, Y.H., T.H. (Tomohiro Hisano) and K.A.; writing-original draft preparation, H.F.; writing—review and editing, S.N., T.H. (Tetsuya Hirata), Y.H. and H.F.; visualization, H.F. All authors have read and agreed to the published version of the manuscript.

Funding: This research received no external funding.

Informed Consent Statement: Not applicable.

Data Availability Statement: Not applicable.

Acknowledgments: We thank Yongsu Kim, Kensuke Tachiki., Makoto Tamesada, Takuya Makino, and Yuki Ozeki for their assistance in experiments, discussions, and literature information. We are grateful to Tazuru Kikkawa of Kamakura Techno-Science, Inc., for performing the pharmacokinetic analysis; Tsutomu Tajikawa from the Department of Mechanical Engineering, Faculty of Engineering Science, Kansai University, for implementation of plasma viscosity experiments; and Skylight Biotech 
Inc., for analysis of lipoproteins. The authors report no conflicts of interest in the preparation of this paper. This research received no specific grant from any funding agency in the public, commercial, or not-for-profit sectors.

Conflicts of Interest: The authors declare no conflict of interest. No funding body had a role in the writing of this review.

Sample Availability: Samples of the compounds are not available from the authors.

\section{References}

1. Endo, A.; Monacolin, K. A new hypocholesterolemic agent produced by a Monuscus species. J. Antibiot. 1979, 32, 852-854. [CrossRef] [PubMed]

2. Endo, A.; Monacolin, K. A new hypocholesterolemic agent that specifically inhibits 3-hydroxy-3-methylglutaryl coenzyme A reductase. J. Antibiot. 1980, 33, 334-336. [CrossRef]

3. Endo, A.; Negishi, Y.; Iwashita, T.; Mizukawa, K.; Hirama, M. Biosynthesis of ML-236B (compactin) and monacolin K. J. Antibiot. 1985, 38, 444-448. [CrossRef]

4. Endo, A. History and recent trends about red koji and Monascus fungi. Ferment. Ind. 1985, 43, 544-552. (In Japanese)

5. Tsukioka, A.; Hiroi, T.; Suzuki, T. Pigment Production by Mutants of Monascus anka. J. JSBBA 1986, 60, 451-455. (In Japanese)

6. Chen, W.; He, Y.; Zhou, Y.; Shao, Y.; Feng, Y.; Li, M.; Chen, F. Edible Filamentous Fungi from the Species Monascus: Early Traditional Fermentations, Modern Molecular Biology, and Future Genomics. Jpn. J. Complem. Altern. Med. $2015,14,555-567$.

7. Nishitani, M.; Inagaki, M. Red Koji (Red Mold Rice) for Complementary and Alternative Medicine as well as for Health Conditioning. Jpn. J. Complem. Altern. Med. 2009, 6, 45-51.

8. Su, Y. Characteristics of Monascus fungi and their usage. J. Brew. Soc. Japan. 1975, 33, 28-36. (In Japanese)

9. Su, Y. Proceeding of the Oriental Fermented Foods; Industry Research and Development Institute: Hsinchu, Taiwan, 1980; pp. 15-30.

10. Itou, H. Utilization of Beni-koji (Monascus koji) for Miso and Soysauce. J. Brew. Soc. Japan. 1994, 89, 948-953. (In Japanese) [CrossRef]

11. Ysasuda, M. Tofuyo and red koji (2). J. Brew. Soc. Japan. 1983, 78, 912-915. (In Japanese)

12. Tarui, S. New material trends of processed foods. (2). Character of Beni koji (red colored malted rice) and its use. Jpn. Food Science. 1993, 32, 35-42. (In Japanese)

13. Mapari, S.A.; Thrane, U.; Meyer, A.S. Fungal polyketide azaphilone pigments as future natural food colorants? Trends Biotechnol. 2010, 28, 300-307. [CrossRef]

14. Patakova, P. Monascus secondary metabolites: Production and biological activity. J. Ind. Microbiol. Biotchnol. 2013, 40, 169-181. [CrossRef] [PubMed]

15. Akihisa, T.; Mafune, S.; Ukiya, M.; Kimura, Y.; Yasukawa, K.; Suzuki, T.; Tokuda, H.; Tanabe, N.; Fukuoka, T. (+)- and (-)-syn-2isobutyl-4-methylazetidine-2,4-dicarboxylic acids from the extract of Monascus pilosus-fermented rice (red-mold rice). J. Nat. Prod. 2004, 67, 479-480. [CrossRef] [PubMed]

16. Akihisa, T.; Tokuda, H.; Yasukawa, K.; Ukiya, M.; Kiyota, A.; Sakamoto, N.; Suzuki, T.; Tanabe, N.; Nishino, H. Azaphilones, furanoisophthalides, and amino acids from the extracts of Monascus pilosus-fermented rice (red-mold rice) and their chemopreventive effects. J. Agric. Food Chem. 2005, 53, 562-565. [CrossRef]

17. Su, Y.C.; Wang, J.J.; Lin, T.T.; Pan, T.M. Production of the secondary metabolites gamma-aminobutyric acid and monacolin K by Monascus. J. Ind. Microbiol. Biotchnol. 2003, 30, 41-46. [CrossRef]

18. Kim, C.; Jung, H.; Kim, Y.O.; Shin, C.S. Antimicrobial activities of amino acid derivatives of monascus pigments. Fems Microbiol. Lett. 2006, 264, 117-124. [CrossRef]

19. Blanc, P.J.; Laussac, J.P.; Bars, J.L.; Bars, P.L.; Loret, M.O.; Pareilleux, A.; Prome, D.; Prome, J.C.; Santerre, A.L.; Goma, G. Characterization of monascidin A from Monascus as citrinin. Int. J. Food Microbiol. 1995, 27, 201-213. [CrossRef]

20. Kohama, Y.; Matsumoto, S.; Mimura, T.; Tanabe, N.; Inada, A.; Nakanishi, T. Isolation and identification of hypotensive principles in red-mold rice. Chem. Pharm. Bull. 1987, 35, 2484-2489. [CrossRef]

21. Razak, D.L.A.; Rashid, N.Y.A.; Jamaluddin, A.; Sharifudin, S.A.; Long, K. Enhancement of phenolic acid content and antioxidant activity of rice bran fermented with Rhizopus oligosporus and Monascus purpureus. Biocatal. Agric. Biotechnol. 2015, 4, 33-38. [CrossRef]

22. Cheng, J.; Choi, B.; Yang, S.H.; Suh, J. Effect of Fermentation on the Antioxidant Activity of Rice Bran by Monascus pilosus KCCM60084. J. Appl. Biol. Chem. 2016, 59, 57-62. [CrossRef]

23. Zhu, B.; Qi, F.; Wu, J.; Yin, G.; Hua, J.; Zhang, Q.; Qin, L. Red Yeast Rice: A Systematic Review of the Traditional Uses, Chemistry, Pharmacology and Quality Control of an Important Chinese Folk Medicine. Front. Pharmacol. 2019, 10, 1449. [CrossRef]

24. Endo, A. Compactin (ML-236B) and related compounds as potential cholesterol-lowering agents that inhibit HMG-CoA reductase. J. Med. Chem. 1985, 28, 401-405. [CrossRef] [PubMed]

25. Endo, A. Regulation of HMG-CoA Reductase; Preiss, B., Ed.; Academic Press: New York, NY, USA, 1985; pp. 49-78.

26. Lee, C.; Wang, J.; Pan, T. Synchronous analysis method for detection of citrinin and the lactone and acid forms of monacolin $\mathrm{K}$ in red mold rice. J. Aoac Int. 2006, 89, 669-677. [CrossRef] [PubMed] 
27. Endo, A. Chemistry, biochemistry and pharmacology of HMG-CoA reductase inhibitors. Klin. Wochenschr. 1988, 66, 421-427. [CrossRef] [PubMed]

28. Wen, Q.; Cao, X.; Chen, Z.; Xiong, Z.; Liu, J.; Cheng, Z.; Zheng, Z.; Long, C.; Zheng, B.; Huang, Z. An overview of Monascus fermentation processes for monacolin K production. Open Chem. 2020, 18, 10-21. [CrossRef]

29. Kim, H.J.; Ji, G.E.; Lee, I.H. Natural Occurring Levels of Citrinin and Monacolin K in Korean Monascus Fermentation Products. Food Sci. Biotechnol. 2007, 16, 142-145.

30. Virk, M.S.; Ramzan, R.; Virk, M.A.; Yuan, X.; Chen, F. Transfigured Morphology and Ameliorated Production of Six Monascus Pigments by Acetate Species Supplementation in Monascus ruber M7. Microorganisms 2020, 8, 81. [CrossRef]

31. Mabuchi, H. Hyperlipidemia and atherosclerosis. J. Jpn. Soc. Intern. Med. 1998, 87, 950-957. (In Japanese) [CrossRef]

32. Frishman, W.H.; Zimetbaum, P.; Nadelmann, J. Lovastatin and other HMG-CoA reductase inhibitors. J. Clin. Pharmacol. 1989, 29, 975-982. [CrossRef] [PubMed]

33. Tobert, J.A. Lovastatin and beyond: The history of the HMG-CoA reductase inhibitors. Nat. Rev. Drug Discov. 2003, 2, 517-526. [CrossRef] [PubMed]

34. Mabuchi, H. Statin drugs. Clin. All-Round. 2007, 56, 2272-2280. (In Japanese)

35. Kazi, D.S.; Penko, J.M.; Bibbins-Domingo, K. Statins for Primary Prevention of Cardiovascular Disease: Review of Evidence and Recommendations for Clinical Practice. Med. Clin. N. Am. 2017, 101, 689-699. [CrossRef]

36. Shibasaki, M.; Saito, Y. Statin drugs and their pleiotropic effects. Prog. Med. 2004, 24, 15-20. (In Japanese)

37. Blum, A.; Shamburek, R. The pleiotropic effects of statins on endothelial function, vascular inflammation, immunomodulation and thrombogenesis. Atherosclerosis 2009, 203, 325-330. [CrossRef]

38. Shoji, T.; Fujii, H.; Tokai, H.; Fujimoto, S.; Wada, T.; Kawano, N.; Tsuchikura, S.; Eiko, L.; Otsuka, Y.; Teramura, M.; et al. A Randomized, Double-blinded, Comparative, Dose-finding Trial to Examine the Cholesterol-lowering Effect of Red Koji in Healthy Volunteers. J. Jpn. Soc. Clin. Nutr. 2008, 29, 425-433. (In Japanese)

39. Shoji, T.; Fukui, M.; Fujii, H. LDL-C lowering effect of red yeast rice-Stratified analysis of a randomized controlled trial including healthy volunteers with borderline hyper-LDL cholesterolemia. Anti Aging Med. 2018, 14, 533-541. (In Japanese)

40. Takemoto, M.; Yoshino, G. Effect of Lovastatin-Containing Red Koji on Plasma Lipid Levels in Hyperlipidemic Subjects. J. Jpn. Soc. Clin. Nutr. 2000, 22, 39-42. (In Japanese)

41. Heinz, T.; Schuchardt, J.P.; Möller, K.; Hadji, P.; Hahn, A. Low daily dose of 3 mg monacolin K from RYR reduces the concentration of LDL-C in a randomized, placebo-controlled intervention. Nutr. Res. 2016, 36, 1162-1170. [CrossRef] [PubMed]

42. Cicero, A.F.G.; Fogacci, F.; Banach, M. Red Yeast Rice for Hypercholesterolemia. Methodist Debakey Cardiovasc. J. 2019, 15, 192-199. [PubMed]

43. Wu, Y.; Zhao, J.; Henion, J.; Korfmacher, W.A.; Lapiguera, A.P.; Lin, C.C. Microsample determination of lovastatin and its hydroxy acid metabolite in mouse and rat plasma by liquid chromatography/ionspray tandem mass spectrometry. J. Mass Spectrom. 1997, 32, 379-387. [CrossRef]

44. Fukami, H.; Ueda, T.; Matsuoka, N. Pharmacokinetic Study of Compound K in Japanese Subjects After Ingestion of Panax ginseng Fermented by Lactobacillus paracasei A221 Reveals Significant Increase of Absorption into Blood. J. Med. Food. 2019, 22, 257-263. [CrossRef]

45. Taco-Vasquez, E.D.; Barrera, F.; Serrano-Duenas, M.; Jimenez, E.; Rocuts, A.; Perez, E.R. Association between Blood Viscosity and Cardiovascular Risk Factors in Patients with Arterial Hypertension in a High Altitude Setting. Cureus 2019, 11, e3925. [CrossRef]

46. Destiana, D.; Timan, I.S. The relationship between hypercholesterolemia as a risk factor for stroke and blood viscosity measured using Digital Microcapillary. J. Phys. 2018, 1073, 042045. [CrossRef]

47. Cho, Y.I.; Cho, D.J. Hemorheology and Microvascular Disorders. Korean Circ. J. 2011, 41, 287-295. [CrossRef] [PubMed]

48. Jung, L.Y.; Lee, S.R.; Jung, J.M.; Kim, Y.S.; Lee, S.H.; Rhee, K.S.; Chae, J.K.; Lee, D.H.; Kim, D.S.; Kim, W.H.; et al. Rosuvastatin Reduces Blood Viscosity in Patients with Acute Coronary Syndrome. Korean Circ. J. 2016, 46, 147-153. [CrossRef]

49. Sipahioglu, N.; Karis, D.; Uzun, H.; Sipahioglu, F.; Ercan, S.; Ercan, A. The Effect of Ezetimibe on Plasma Viscosity, Fibrinogen and Lipid Profile. Med. Sci. Discov. 2015, 2, 339-344. [CrossRef]

50. Baskurt, O.K.; Boynard, M.; Cokelet, G.C.; Connes, P.; Cooke, B.M.; Forconi, S.; Liao, F.; Hardeman, M.R.; Jung, F.; Meiselman, H.J.; et al. New guidelines for hemorheological laboratory techniques. Clin. Hemorheol. Microcirc. 2009, 42, 75-97. [CrossRef]

51. Usui, N.; Iwata, K.; Miyachi, T.; Takagai, S.; Wakusawa, K.; Nara, T.; Tsuchiya, K.J.; Matsumoto, K.; Kurita, D.; Kameno, Y.; et al. VLDL-specific increases of fatty acids in autism spectrum disorder correlate with social interaction. EBioMedicine 2020, $58,102917$. [CrossRef] [PubMed]

52. Zhu, B.; Sievers, R.E.; Sun, Y.; Isenberg, W.M.; Parmley, W.W. Effect of lovastatin on suppression and regression of atherosclerosis in lipid-fed rabbits. J. Cardiovasc. Pharmacol. 1992, 19, 246-255. [CrossRef] [PubMed]

53. Aviram, M.; Hussein, O.; Rosenblat, M.; Schlezinger, S.; Hayek, T.; Keidar, S. Interactions of platelets, macrophages, and lipoproteins in hypercholesterolemia: Antiatherogenic effects of HMG-CoA reductase inhibitor therapy. J. Cardiovasc. Pharmacol. 1998, 31, 39-45. [CrossRef]

54. Lin, R.; Liu, J.; Peng, N.; Yang, G.; Gan, W.; Wang, W. Lovastatin reduces nuclear factor kappaB activation induced by C-reactive protein in human vascular endothelial cells. Biol. Pharm. Bull. 2005, 28, 1630-1634. [CrossRef] [PubMed]

55. Gross, V.; Schneider, W.; Schunck, W.H.; Mervaala, E.; Luft, F.C. Chronic effects of lovastatin and bezafibrate on cortical and medullary hemodynamics in deoxycorticosterone acetate-salt hypertensive mice. J. Am. Soc. Nephrol. 1999, 10, 1430-1439. 
56. Giannopoulos, S.; Katsanos, A.H.; Tsivgoulis, G.; Marshall, R.S. Statins and cerebral hemodynamics. J. Cereb. Blood Flow Metab. 2012, 32, 1973-1976. [CrossRef] [PubMed]

57. Farah, C.; Michel, L.Y.M.; Balligand, J.L. Nitric oxide signalling in cardiovascular health and disease. Nat. Rev. Cardiol. 2018, 15, 292-316. [CrossRef]

58. Merhi, M.; Dusting, G.J.; Khalil, Z. CGRP and nitric oxide of neuronal origin and their involvement in neurogenic vasodilatation in rat skin microvasculature. Br. J. Pharmacol. 1998, 123, 863-868. [CrossRef] [PubMed]

59. Umeji, K.; Umemoto, S.; Itoh, S.; Tanaka, M.; Kawahara, S.; Fukai, T.; Matsuzaki, M. Comparative effects of pitavastatin and probucol on oxidative stress, $\mathrm{Cu} / \mathrm{Zn}$ superoxide dismutase, PPAR-gamma, and aortic stiffness in hypercholesterolemia. Am. J. Physiol. Heart Circ. Physiol. 2006, 291, H2522-H2532. [CrossRef] [PubMed]

60. Shafi, O. Switching of vascular cells towards atherogenesis, and other factors contributing to atherosclerosis: A systematic review. Thromb J. 2020, 18, 28. [CrossRef]

61. Ikeda, U.; Shimpo, M.; Ikeda, M.; Minota, S.; Shimada, K. Lipophilic statins augment inducible nitric oxide synthase expression in cytokine-stimulated cardiac myocytes. J. Cardiovasc. Pharmacol. 2001, 38, 69-77. [CrossRef] [PubMed]

62. Zhao, T.T.; Le Francois, B.G.; Goss, G.; Ding, K.; Bradbury, P.A.; Dimitroulakos, J. Lovastatin inhibits EGFR dimerization and AKT activation in squamous cell carcinoma cells: Potential regulation by targeting rho proteins. Oncogene 2010, 29, 4682-4692. [CrossRef]

63. Xu, R.; Chen, J.; Cong, X.; Hu, S.; Chen, X. Lovastatin protects mesenchymal stem cells against hypoxia- and serum deprivationinduced apoptosis by activation of PI3K/Akt and ERK1/2. J. Cell Biochem. 2008, 103, 256-269. [CrossRef]

64. Zhu, X.Y.; Li, P.; Yang, Y.B.; Liu, M.L. Xuezhikang, extract of red yeast rice, improved abnormal hemorheology, suppressed caveolin-1 and increased eNOS expression in atherosclerotic rats. PLoS ONE 2013, 8, e62731. [CrossRef] [PubMed]

65. Fujimura, S.; Shimakage, H.; Tanioka, H.; Yoshida, M.; Suzuki-Kusaba, M.; Hisa, H.; Satoh, S. Effects of GABA on noradrenaline release and vasoconstriction induced by renal nerve stimulation in isolated perfused rat kidney. Br. J. Pharmacol. 1999, 127, 109-114. [CrossRef] [PubMed]

66. Hayakawa, K.; Kimura, M.; Kamata, K. Mechanism underlying gamma-aminobutyric acid-induced antihypertensive effect in spontaneously hypertensive rats. Eur. J. Pharmacol. 2002, 438, 107-113. [CrossRef]

67. Hayakawa, K.; Kimura, M.; Yamori, Y. Role of the renal nerves in gamma-aminobutyric acid-induced antihypertensive effect in spontaneously hypertensive rats. Eur. J. Pharmacol. 2005, 524, 120-125. [CrossRef]

68. Monasterolo, L.A.; Trumper, L.; Elías, M.M. Effects of gamma-aminobutyric acid agonists on the isolated perfused rat kidney. J. Pharmacol. Exp. Ther. 1996, 279, 602-607.

69. Ehara, S.; Ueda, M.; Naruko, T.; Haze, K.; Itoh, A.; Otsuka, M.; Komatsu, R.; Matsuo, T.; Itabe, H.; Takano, T.; et al. Elevated levels of oxidized low density lipoprotein show a positive relationship with the severity of acute coronary syndromes. Circulation 2001, 103, 1955-1960. [CrossRef]

70. Laufs, U.; Fata, V.L.; Plutzky, J.; Liao, J.K. Upregulation of endothelial nitric oxide synthase by HMG CoA reductase inhibitors. Circulation 1998, 97, 1129-1135. [CrossRef] [PubMed]

71. Anderson, T.J.; Meredith, I.T.; Yeung, A.C.; Frei, B.; Selwyn, A.P.; Ganz, P. The effect of cholesterol-lowering and antioxidant therapy on endothelium-dependent coronary vasomotion. N. Engl. J. Med. 1995, 332, 488-493. [CrossRef] [PubMed]

72. Srianta, I.; Zubaidah, E.; Estiasih, T.; Iuchi, Y.; Harijono, H.; Yamada, M. Antioxidant activity of pigments derived from Monascus purpureusfermented rice, corn, and sorghum. Int. Food Res. J. 2017, 24, 1186-1191.

73. Wada, M.; Kido, H.; Ohyama, K.; Ichibangase, T.; Kishikawa, N.; Ohba, Y.; Nakashima, M.N.; Kuroda, N.; Nakashima, K. Chemiluminescent screening of quenching effects of natural colorants against reactive oxygen species: Evaluation of grape seed, monascus, gardenia and red radish extracts as multi-functional food additives. Food Chem. 2007, 101, 980-986. [CrossRef]

74. Lee, C.L.; Wen, J.Y.; Hsu, Y.W.; Pan, T.M. The blood lipid regulation of Monascus-produced monascin and ankaflavin via the suppression of low-density lipoprotein cholesterol assembly and stimulation of apolipoprotein A1 expression in the liver. J. Microbiol. Immunol. Infect. 2018, 51, 27-37. [CrossRef]

75. Hermans, N.; Van der Auwera, A.; Breynaert, A.; Verlaet, A.; De Bruyne, T.; Van Gaal, L.; Pieters, L.; Verhoeven, V. A red yeast rice-olive extract supplement reduces biomarkers of oxidative stress, OxLDL and Lp-PLA 2, in subjects with metabolic syndrome: A randomised, double-blind, placebo-controlled trial. Trials 2017, 18, 302. [CrossRef] [PubMed]

76. Kono, I. Development of food materials that have the effect of improving vascular endothelial function. J. Brew. Soc. Jpn. 2012, 107, 750-759. (In Japanese) [CrossRef]

77. Hsu, W.H.; Chen, T.H.; Lee, B.H.; Hsu, Y.W.; Pan, T.M. Monascin and ankaflavin act as natural AMPK activators with PPAR $\alpha$ agonist activity to down-regulate nonalcoholic steatohepatitis in high-fat diet-fed C57BL/6 mice. Food Chem. Toxicol. 2014, 64, 94-103. [CrossRef]

78. Ting, H.H.; Timimi, F.K.; Boles, K.S.; Creager, S.J.; Ganz, P.; Creager, M.A. Vitamin C improves endothelium-dependent vasodilation in patients with non-insulin-dependent diabetes mellitus. J. Clin. Investig. 1996, 97, 22-28. [CrossRef] [PubMed]

79. Higashi, Y.; Sasaki, S.; Nakagawa, K.; Ueda, T.; Yoshimizu, A.; Kurisu, S.; Matsuura, H.; Kajiyama, G.; Oshima, T. A comparison of angiotensin-converting enzyme inhibitors, calcium antagonists, beta-blockers and diuretic agents on reactive hyperemia in patients with essential hypertension: A multicenter study. J. Am. Coll. Cardiol. 2000, 35, 284-291. [CrossRef] 
80. Sasaki, S.; Higashi, Y.; Nakagawa, K.; Kimura, M.; Noma, K.; Sasaki, S.; Hara, K.; Matsuura, H.; Goto, C.; Oshima, T.; et al. A low-calorie diet improves endothelium-dependent vasodilation in obese patients with essential hypertension. Am. J. Hypertens. 2002, 15, 302-309. [CrossRef]

81. Xiong, Z.; Cao, X.; Wen, Q.; Chen, Z.; Cheng, Z.; Huang, X.; Zhang, Y.; Long, C.; Zhang, Y.; Huang, Z. An overview of the Bioactivity of monacolin K / lovastatin. Food Chem. Toxicol. 2019, 131, 110585. [CrossRef]

82. Shimizu, T.; Kinoshita, H.; Ishihara, S.; Sakai, K.; Nagai, S.; Nihira, T. Polyketide synthase gene responsible for citrinin biosynthesis in Monascus purpureus. Appl. Environ. Microbiol. 2005, 71, 3453-3457. [CrossRef]

83. Wang, M.; Jiang, N.; Xian, H.; Wei, D.; Shi, L.; Feng, X. Effects of Light Intensity and Color on the Biomass, Extracellular Red Pigment, and Citrinin Production of Monascus ruber. J. Chromatogr. A 2016, 1429, 22-29. [CrossRef] [PubMed]

84. Higa, Y.; Kim, Y.; Altaf-Ul-Amin, M.; Huang, M.; Ono, N.; Kanaya, S. Divergence of metabolites in three phylogenetically close Monascus species (M. pilosus, M. ruber, and M. purpureus) based on secondary metabolite biosynthetic gene clusters. BMC Genom. 2020, 21, 679. [CrossRef] [PubMed] 